\title{
REGULAMENTUL ADMINISTRATIV ȘI LEGEA ORGANICĂ, FAȚĂ ÎN FAȚĂ: ÎNTRE CONVIET,UIRE ȘI CONFLICT
}

\section{Andreea-Carla LOGHIN*}

Rezumat: În acord cu prevederile constituționale și cu principiul ierarhiei normelor juridice, prin act administrativ normativ („regulament”) nu pot fi instituite reguli în domenii ce fac obiectul exclusiv al legii organice (potrivit art. 73 din Constituția României) iar, în măsura în care s-ar întâmpla acest lucru, în fața instanței prioritate trebuie să aibă legea, și nu un act infralegal, căci, așa cum stabilește imperativ art. 124 din Constituție: „... judecătorii se supun numai legii”. Consiliul Superior al Magistraturii este organul administrativ cu atribuții recunoscute de lege în materia carierei magistraților, având competența de a adopta acte administrative normative și de a reglementa proceduri specifice de organizare a concursurilor de promovare în funcție a magistraților. În măsura în care o lege organică îi permite acestuia să instituie prin hotărâre reguli de contencios administrativ, se ivește un conflict de reglementări între un asemenea regulament/act administrativ normativ și Legea nr. 554/2004 a contenciosului administrativ - „dreptul comun” în această materie. Sesizată fiind cu soluționarea unei contestații, Înalta Curte de Casație și Justiție pare să facă abstracție de principiile constituționale, ridicând actul administrativ normativ la rangul de „lege” pentru a exclude de la aplicare legea organică în materia contenciosului administrativ.

Regula prevăzută de art. 2 alin. (1) lit. h) din Legea nr. 554/2004 este aceea că termenul de care orice organ administrativ dispune pentru a răspunde cererii

* Avocat în Baroul Cluj, andreea-carla.loghin@law.ubbcluj.ro. 
particularului cu care a fost sesizat este de 30 de zile. Regulamentul Consiliului Superior al Magistraturii în cauză stabilește un termen de 90 de zile în care magistratul care a fost declarat admis la concurs, fără a se fi clasat pe o poziție care să-i fi permis să ocupe unul din locurile pentru care a concurat, poate valorifica rezultatele concursului în vederea promovării, dacă, în acest interval de timp se vacantează un loc la instanța pentru care a optat. Interpretând acest termen, într-o manieră surprinzătoare și, într-o oarecare măsură, ambiguă, Înalta Curte de Casație și Justiție pare a-i conferi aceeași natură juridică cu termenul instituit prin legea organică în materie de contencios administrativ, excluzând aplicabilitatea acestuia din urmă. Prezentul studiu a1nalizează natura juridică a termenului de 90 de zile și locul acestuia în logica termenelor din contenciosul administrativ pentru a concluziona că soluția dată de instanța supremă conflictului de reglementări și raportului dintre termenele aplicabile este cel puțin criticabilă.

Cuvinte cheie: Consiliul Superior al Magistraturii, act administrativ normativ, contencios administrativ, lege organică, principiul ierarhiei normelor juridice, art. 2 alin. (1) lit. h) din Legea nr. 554/2004, cariera magistraților, concurs de promovare.

\title{
ADMINISTRATIVE REGULATIONS AND ORGANIC LAW: BETWEEN CONFLICT AND CONSONANCE
}

\begin{abstract}
Under the Romanian constitutional provisions and the principle of the hierarchy of legal norms, normative administrative regulations cannot enforce rules in areas that are the exclusively subject to the organic law (according to art. 73 of the Constitution) and, insofar as this would happen, the law must have priority before the court, and not an illegal act, because, art. 124 of the Constitution states that 'judges are subject only to the law.' The Romanian Superior Council of Magistracy is the administrative body with attributions recognised by law in matters related to magistrates' careers: It can adopt normative administrative acts and regulate specific procedures for organising competitions to promote magistrates. To the extent that an organic law allows it to establish, by decision, rules of administrative litigation, there is a conflict of regulations between such a normative administrative act and Law no. $554 / 2004$ of the administrative contentious - lex generalis in this matter. Having been notified with the settlement of an appeal, the Romanian High Court of Cassation and Justice seems to ignore the constitutional principles, raising the normative
\end{abstract}


administrative act to the rank of 'law' in order to exclude the application of the organic law on administrative litigation.

The rule provided by article 2 paragraph (1) letter h) of Law no. 554/2004 states that the administration must respond to an individual's request within 30 days. The regulation of the Romanian Superior Council of Magistracy in question establishes a term of 90 days in which the one who was declared admitted to the competition, without having been classified on a place that would have allowed him/her to occupy one of the places for which he/she competed, can capitalise the results of the contest in order to be promoted, if, during this time, a place is vacated at the court for which he/she opted. Interpreting this term in a surprising and, to some extent, ambiguous manner, the Romanian High Court seems to give it the same legal nature as the term set up by the organic law on administrative litigation, excluding the latter's applicability. This study examines the legal nature of the 90-day time limit and its place in the logic of time limits in administrative litigation to conclude that the solution given by the Supreme Court to the conflict of regulations and the relationship between the applicable time limits is at least questionable.

Keywords: Superior Council of Magistracy, normative administrative act, administrative contentious, organic law, the principle of the hierarchy of legal norms, art. 2 para. (1) letter h) of Law no. 554/2004, the career of magistrates, promotion contest. 


\section{Cuprins}

I. Despre posibilitatea delegării către CSM a atribuției de a „legifera” în

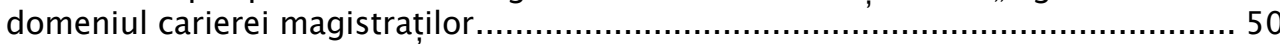

A. Delegarea” de putere legislativă și contenciosul administrativ ............ 53

1.Totul pleacă de la o regulă ......................................................... 53

2.Delegarea legislativă „comună” - Ordonanțele Guvernului .................. 55

3.Delegarea legislativă „improprie”................................................. 58

B. Delegarea legislativă și cariera magistraților ................................................61

1.Incidența regulilor de contencios administrativ în ceea ce privește cariera magistraților

2.Interdicția expresă de a adăuga la lege ........................................... 62

3. Mecanismul de apreciere, de către instanța de judecată, a legalității unui act administrativ normativ adoptat de CSM ..................... 64

II. Natura termenului de 90 de zile de valorificare a rezultatelor concursului 68

A. Despre termene în general și posibilele lor clasificări .................................68

1.Drepturile subiective și termenele care le afectează existența sau, după caz, eficacitatea. 68

2.Actele de procedură și termenele în care trebuie îndeplinite

acestea..................................................................................... 76

B. Despre termenul de $\mathbf{9 0}$ de zile și corelarea lui cu termenele reglementate de Legea nr. 554/2004 a contenciosului administrativ.

1.Logica termenelor în contenciosul administrativ în situația refuzului nejustificat de solutionare a unei cereri 82

2.Termenul de 90 de zile instituit prin Regulamentul CSM și natura sa juridică dificil de găsit

3.Unde a greșit instanța supremă în interpretarea sa?.......................... 96

III. Concluzie 103

Să ne imaginăm următorul scenariu: o persoană se înscrie la un concurs de promovare în funcție, condiționat de existența (cel puțin a) unui loc vacant la instituția vizată. La final, aceasta se situează pe a treia poziție în lista candidaților, în condițiile în care fuseseră scoase la concurs doar două locuri. Procedura de desfăşurare a concursului prevede însă că, ulterior validării rezultatelor, candidații care nu se numără printre cei promovați (deși au fost declarați admiși, obținând un punctaj care, în abstract, le-ar fi permis 
să ocupe postul) au dreptul de a-şi valorifica rezultatele obținute și de a reitera cererea de promovare dacă, între timp, în cadrul instituției în cauză apare un alt loc vacant. Vocaţia la valorificarea rezultatelor și la promovare există însă pentru un interval de timp limitat. O persoană aflată într-o asemenea situație, formulează cererea necesară, cu speranța legitimă că va primi un răspuns în termenul legal (general). În ciuda existenței locului vacant în perioada imediat următoare solicitării sale (deci a îndeplinirii tuturor condițiilor legale), organul administrativ sesizat păstrează tăcerea timp de 30 de zile. Răspunsul negativ este comunicat doar la expirarea termenului care limita temporal vocația de promovare, când locul vacant se ocupase deja, iar vocația la valorificarea rezultatelor primului concurs nu mai exista. Să fi fost această a doua șansă una reală și efectivă sau, mai degrabă, doar „teoretică și iluzorie"?

Dar, mai întâi să vedem care a fost soluția instanței supreme de la care pornește prezentul studiu:

„ (...) Potrivit dispozițiilor art. 46 alin. (3) și art. 47 din Legea nr. 303/2004, modificată și completată, procedura de organizare și desfășurare a concursului de promovare a judecătorilor și procurorilor va fi stabilită printr-un Regulament. De asemenea, dispozițiile art. 60 din Legea nr. 303/2004, modificată și completată, stipulează în sensul stabilirii competenței CSM de a aproba cererile de transfer ale judecătorilor și procurorilor de la o instanță la alta sau de la un parchet la alt parchet ori la o instituție publică. La rândul său, art. 38 alin. (1) din Legea nr. 317/2004 modificată și completată, enumeră printre atribuțiile Plenului CSM adoptarea regulamentelor și hotărârilor prevăzute de Legea nr. 303/2004 și Legea nr. 304/2004. 
În acest scop, prin Hotărârea Plenului CSM nr. 621/20061, modificată şi completată, a fost adoptat Regulamentul privind organizarea şi desfăşurarea concursului de promovare a judecătorilor şi procurorilor, act administrativ cu caracter normativ care, la art. 30 alin. (1), prevede că judecătorii și procurorii care nu au fost promovați ca urmare a lipsei posturilor vacante pot fi promovați în posturile ce se vacantează la instanțele și parchetele pentru care au optat la înscriere, în termen de $3 \operatorname{luni}^{2}$ de la data validării concursului.

Din cuprinsul dispozițiilor Legii nr. $303 / 2004^{3}$ și Legii nr. 317/20044, se desprinde concluzia conform căreia, procedurile de promovare şi transfer ale judecătorilor şi procurorilor sunt lăsate în competența Consiliului Superior al Magistraturii care, prin intermediul regulamentelor şi hotărârilor, are obligația să emită dispoziții de organizare a executării legii și de executare în concret a legii. Astfel, art. 30 alin. (1) din Regulamentul privind organizarea și desfăşurarea concursului de promovare a judecătorilor și procurorilor a stabilit un termen de 3 luni pentru valorificarea rezultatelor concursului de promovare.

Contestatoarea a susținut că, potrivit art. 2 alin. (1) lit. h) din Legea contenciosului administrativ , era îndreptățită să obțină un răspuns la cererea sa de valorificare, în termen de 30 de zile de la data de 19.12.2017 ce reprezintă data validării rezultatelor obținute la concursul de promovare din data de 26.11.2017.

Înalta Curte apreciază că dispozițiile art. 2 alin. (1) lit. h) din Legea nr. 554/2004 modificată și completată nu sunt aplicabile în cauză. Legea contenciosului administrativ reprezintă legea generală în

\footnotetext{
1 Consiliul Superior al Magistraturii, Plen, Hotărâre nr. 621/2006, http://old.csm1909.ro/csm/linkuri/25 $102006 \quad 6439$ ro.pdf, https://perma.cc/8CLV-5XCZ.

${ }^{2}$ Forma actuală a Hotărârii nr. 621/2006 adoptată de Plenul CSM prevede un termen de 6 luni pentru valorificarea rezultatelor concursului.

3 Publicată în M.of.: 576/29 iunie 2004, republicată în temeiul art. XII al titlului XVII din Legea nr. 247/2005 în M.of.: 826/13 septembrie 2005, în vigoare din 29 septembrie 2004.

4 Publicată în M.of.: 599/2 iulie 2004, republicată în M. of.: 827/13 septembrie 2005, republicată în temeiul art. 80 din Legea nr. 76/2012 în M. of.: 628/1 septembrie 2012, în vigoare din 2 octombrie 2004.

5 Publicată în M.of.: 1154/7 decembrie 2004, în vigoare din 7 ianuarie 2005.
} 
materia contenciosului administrativ, iar termenul de 30 de zile se aplică în domeniile în care, prin legi speciale nu se prevede un alt termen.

Contestatoarea a mai susținut, prin concluziile orale, faptul că Legea contenciosului administrativ este o lege organică, conform art. 73 alin. (3) lit. k) din Constituția României, iar termenul de 30 de zile poate fi modificat numai prin lege organică și nu printr-un Regulament, act administrativ cu caracter normativ.

Înalta Curte de Casație și Justiție amintește dispozițiile art. 73 alin. (3) lit. l) din Constituția României, potrivit cărora organizarea și funcționarea Consiliului Superior al Magistraturii se reglementează prin lege organică, iar Legea nr. 317/2004 a permis chiar consiliului să adopte regulamente și hotărâri în materia promovării judecătorilor şi procurorilor.

Într-o altă ordine de idei, chiar legea contenciosului administrativ permite ca, prin legi speciale, să se deroge de la termenul general de 30 de zile. Noțiunea de „legi speciale" folosită în cuprinsul Legii nr. 554/2004 este foarte largă, aceasta cuprinzând atât legi organice, dar și legi ordinare sau legea în sens larg, cum ar fi un act administrativ cu caracter normativ.

Prin urmare, Legea nr. 317/2004 privind organizarea şi funcționarea Consiliului Superior al Magistraturii, lege organică, a lăsat în competența de reglementare a acestei autorități întreaga procedură de promovare, care cuprinde și dispoziții referitoare la termenele în care se formulează cererile, răspunsul la cereri etc. astfel că nu este întemeiată susținerea contestatoarei. De altfel, în speță nu a fost invocată nicio excepție de neconstituționalitate sau nelegalitate cu privire la textele incidente.

Înalta Curte concluzionează, arătând că termenul de 30 de zile din Legea nr. 554/2004 modificată și completată nu se aplică în cadrul procedurii valorificării rezultatelor concursului de promovare.

În cauză se aplică numai termenul de 3 luni prevăzut de art. 30 alin. (1) din Regulament, iar la împlinirea acestui termen intimatul are obligația să soluționeze cererea contestatoarei prin care a cerut 
valorificarea rezultatelor concursului de promovare din data de 26.11.2017".

Lectura soluției jurisprudențiale adaugă scenariului propus şi coordonatele lipsă: persoana în cauză are statutul de magistrat (judecător sau procuror), concursul la care participă este un concurs de promovare în funcție, iar perioada de valorificare a rezultatelor concursului este instituită prin regulament adoptat de Plenul Consiliului Superior al Magistraturii. Regulamentul în cauză prevede o procedură specifică prin care pot promova judecătorii și procurorii care, iniţial nepromovați, au trecut de un anumit rezultat prag în urma concursului şi îndeplinesc criteriul unor note minime la materiile enumerate în Regulament7. Acest „drept” născut post-factum este recunoscut doar pentru un interval de 3 luni de la data la care au fost validate rezultatele concursului.

Pornind de la premisa că în domeniul promovării magistraților în funcţie, Consiliul Superior al Magistraturii adoptă hotărâri care instituie proceduri specifice, și ținând cont de faptul că eventualele contestații privitoare la aceste proceduri sunt de competența Secției de contencios administrativ şi fiscal a Înaltei Curți de Casație şi Justiție, un subiect de interes poate fi reprezentat de interferențele existente între astfel de

6 ICCJ, Sec. contencios administrativ şi fiscal, dec.: 3696/1-11-2018, https://sintact.ro/\#/jurisprudence/520810929/1/decizie-nr-3696-2018-din-01-nov-2018inalta-curte-de-casatie-si-justitie-bucuresti.

7 Art. 27 alin. (1) din Regulamentul privind organizarea şi desfăşurarea concursului de promovare a judecătorilor și procurorilor adoptat prin Hotărârea Plenului Consiliului Superior al Magistraturii nr. 621/2006 prevede că „Nota obținută la concurs este suma notelor obținute la proba teoretică și proba practică, în raport cu următoarea pondere: $75 \%$ proba practică și 25\% proba teoretică”, iar potrivit alin. (2) „Pentru a fi declarat admis la concurs candidatul trebuie să obțină cel puțin media generală 7 și nu mai puțin de 5 la fiecare dintre cele două probe de concurs menționate la art. 17”. 
regulamente și Legea nr. 554/2004 a contenciosului administrativ ${ }^{8}$, reprezentând „dreptul comun” în această materie.

Întrebările care se ridică și pe care Înalta Curte de Casaţie şi Justiție le-a tranșat într-o manieră proprie privesc măsura în care o dispoziție cuprinsă în aceste regulamente poate fi interpretată ca prevedere specială, înlăturând de la aplicare regula generală instituită prin Legea nr. 554/2004 a contenciosului administrativ și, totodată, posibilitatea ca o astfel de interpretare să aducă atingere drepturilor magistratului.

În studiul nostru, vom încerca să analizăm, pe de o parte, ce probleme de constituționalitate poate ridica delegarea, printr-o lege organică, a competenței în materie de legiferare către un organ cum este Consiliul Superior al Magistraturii (Partea I), respectiv, care este natura termenului de valorificare a rezultatelor concursului prevăzut în Regulamentul Consiliului Superior al Magistraturii și ce raporturi se pot stabili între acest termen şi cele prevăzute în materia contenciosului administrativ în situaţia refuzului nejustificat de a soluționa o cerere (Partea a II-a).

\section{Despre posibilitatea delegării către CSM a atribuției de a „legifera” în domeniul carierei magistraților}

Trasarea unor legături între actele normative adoptate de Consiliul Superior al Magistraturii și Legea contenciosului administrativ are ca punct de plecare natura administrativă a acestui organ și a hotărârilor sale.

8 Publicată în M.of.: 1154/ 7 decembrie 2004, cu modificările și completările ulterioare. 
Astfel, Consiliul Superior al Magistraturii constituie, fără îndoială, un organ de natură administrativă, în acest sens pronunțându-se și Curtea Constituțională a României9. Totodată, este unanim acceptat că hotărârile acestui organ constituie acte administrative, în considerarea celor două texte din Legea contenciosului administrativ - art. 2 alin. (1) lit. b), unde este definită noțiunea de autoritate publică și lit. c) a aceluiași articol, cuprinzând definiția actului administrativ ${ }^{10}$.

Legea nr. 317/2004 privind Consiliul Superior al Magistraturiii ${ }^{11}$ statuează asupra procedurii de adoptare a hotărârilor de către acest organ ${ }^{12}$.

9 Astfel, în jurisprudența sa, Curtea Constituțională a României decis că CSM este o autoritate fundamentală a statului (Deciziile CCR nr. 53 și nr. 54 din 25 ianuarie 2011, publicate în M.of.: 90/3 februarie 2011), care însă nu este reprezentantul autorității judecătorești, acest rol revenind Înaltei Curți de Casație și Justiție și celorlalte instanțe judecătorești; de asemenea, CSM nu este exponentul puterii judecătorești, ci un organ de natură administrativă (Decizia CCR nr. 375 din 6 iulie 2005, publicată în M.of.: 591/8 iulie 2005). Consiliul este un organism independent, cu activitate permanentă, cu atribuții referitoare la cariera judecătorilor și procurorilor (Decizia CCR nr. 799 din 17 iunie 2011, publicată în M.of.: 440/23 iunie 2011). Conform dispozițiilor constituționale, CSM face parte din cadrul autorităților judecătorești (Decizia CCR nr. 514 din 29 mai 2007, publicată în M.of.: 464/10 iulie 2007). În acest context, autorității judecătorești nu îi poate fi conferit un alt statut față de organele reprezentative ale celorlalte puteri în stat.

${ }^{10}$ Potrivit art. 2 alin. (1) lit. b) din Legea nr. 554/2004, autoritatea publică este definită ca fiind „orice organ de stat sau al unităţilor administrativ-teritoriale care acţionează, în regim de putere publică, pentru satisfacerea unui interes legitim public; sunt asimilate autorităților publice, în sensul prezentei legi, persoanele juridice de drept privat care, potrivit legii, au obținut statut de utilitate publică sau sunt autorizate să presteze un serviciu public, în regim de putere publică”. Totodată, art. 2 alin. (1) lit. c) din Legea nr. 554/2004 oferă definiția actului administrativ ca fiind „actul unilateral cu caracter individual sau normativ emis de o autoritate publică, în regim de putere publică, în vederea organizării executării legii sau a executării în concret a legii, care dă naștere, modifică sau stinge raporturi juridice”.

${ }^{11}$ Republicată în M. Of. nr. 365 din 30 mai 2012.

12 Potrivit art. 29 din Legea nr. 317/2004 : „[...] (4) Hotărârile Consiliului Superior al Magistraturii, în plen și în secții, se iau prin vot direct și secret și se motivează. (5) Hotărârile 
Printre aceste acte se numără şi Regulamentele privind organizarea și desfăşurarea concursurilor de promovare în funcție a magistraților ${ }^{13}$, care au natura unor acte administrative normative ${ }^{14}$.

Caracterul de act administrativ al Hotărârilor Plenului Consiliului Superior al Magistraturii privind cariera judecătorilor și a procurorilor și în principal regimul contestației prevăzute împotriva unei asemenea hotărâri, determină natura de drept administrativ a conflictului dintre magistratul care se consideră vătămat și CSM, și, implicit, o potențială aplicare a regulilor de contencios administrativ.

plenului privind cariera și drepturile judecătorilor și procurorilor se redactează în cel mult 20 de zile şi se comunică de îndată [...]"

13 Competența Consiliului Superior al Magistraturii în adoptarea acestor Regulamente este recunoscută prin Legea nr. 304/2004 privind statutul judecătorilor şi al procurorilor, republicată în M. Of. nr. 653 din 22 iulie 2005, care prevede, în art. 46, cu referire la promovarea acestora, că „procedura de desfășurare a concursului, [...] se stabilește prin Regulamentul privind organizarea și desfășurarea concursului de promovare a judecătorilor și procurorilor”, adăugând, prin art. 106: „Consiliul Superior al Magistraturii aprobă, prin hotărâre care se publică în Monitorul Oficial al României, Partea I:[...] f) Regulamentul privind organizarea și desfășurarea concursului de promovare a judecătorilor și procurorilor [...]”. Competența Consiliului Superior al Magistraturii în ceea ce privește cariera magistraților este confirmată și prin Legea nr. 317/2004 privind Consiliul Superior al Magistraturii. Potrivit art. 30 al acestei legi, „Consiliul Superior al Magistraturii asigură respectarea legii și a criteriilor de competență și etică profesională în desfășurarea carierei profesionale a judecătorilor și procurorilor (...)".

14 De altfel, doctrina și jurisprudența interbelică foloseau doar noțiunea de „acte-reguli”, „regulamente” pentru actele administrative cu caracter normativ. În acest sens, subliniind distincția acte-reguli, acte-subiective, acte-condițiuni, doctrina se exprima în sensul că „Tipul actului-regulă pe care îl poate săvârși Administrațiunea, este regulamentul, care este actul administrativ prin care se stabilesc unele norme cu caracter general și impersonal, întocmai ca și legile, în vederea aplicării legilor și a funcționării, de cele mai multe ori din punct de vedere interior, a serviciilor publice" (C.G. RARINCESCU, Contenciosul administrativ român, ed. a 2-a, anastatică, Ed. Universul Juridic, București, 2019, p. 144). 


\section{A. „Delegarea” de putere legislativă ${ }^{15}$ și contenciosul administrativ}

1. Totul pleacă de la o regulă ...

Posibilitatea de reglementare, privită în sens larg, se manifestă prin adoptarea legilor, pe de o parte și a actelor administrative normative, pe de altă parte. Această distincție clară este făcută și de art. 154 din Constituția României, prin folosirea sintagmei „legile și toate celelalte acte normative”.

În ceea ce privește legile, art. 73 din Constituție, având denumirea marginală „Categorii de legi”, prevede faptul că parlamentul adoptă „legi constituționale, legi organice și legi ordinare”, enumerând apoi domeniile reglementate prin legi organice.

Potrivit alin. (3) lit. k) din același articol, contenciosul administrativ trebuie reglementat exclusiv prin lege organică. În acest sens, sunt de reținut și prevederile art. 52 alin. (1) din Constituția României potrivit cărora „condițiile și limitele exercitării acestui drept [al celui de acces la instanța de contencios administrativ - s.n. A-C.L] se stabilesc prin lege organică." Aceste dispoziții se completează cu art. 5 alin. (2) din Legea nr. 554/2004, care prevăd, la rândul lor, că limitarea dreptului de acces la instanța de

\footnotetext{
15 Prin folosirea noțiunii de „delegare” nu evocăm acea formă de transmitere a competenței întâlnită în dreptul administrativ - desemnând învestirea unui funcționar (delegat) cu exercițiul anumitor atribuții, prin voința organului care deține competența originară (delegant), ci tradiționala „delegare legislativă” însemnând transferul puterii dinspre Parlament spre executiv, pentru a vedea dacă acest fenomen consacrat la nivel constituţional poate avea şi un alt „destinatar” decât guvernul, în speță - Consiliul Superior al Magistraturii.
} 
contencios administrativ prin reglementarea unor proceduri paralele poate fi instituită exclusiv prin lege organică ${ }^{16}$.

Ca o consecință firească, și regula privind termenul pe care administrația îl are la dispoziție pentru a răspunde cererii particularului instituită prin art. 2 alin. (1) lit. h) din Legea nr. 554/2004 ${ }^{17}$ - are natura juridică a unei legi organice.

16 Potrivit art. 5 alin. (2) Legea nr. 554/2004: „Nu pot fi atacate pe calea contenciosului administrativ actele administrative pentru modificarea sau desființarea cărora se prevede, prin lege organică, o altă procedură judiciară”. În legătură cu acest text legal, s-a arătat în doctrină că „(...) recursul paralel presupune existența unei legi organice (sau ordonanțe de urgență emise în domeniul legii organice) care să prevadă o altă procedură judiciară, prin urmare sunt excluse legile ordinare și, cu atât mai mult, procedurile administrativ-jurisdicționale”. Același autor arată că probleme de interpretare au apărut în ceea ce privește OG: 2/2001 privind contravențiile, exprimându-se în sensul că „aplicând strict textele Legii nr. 554/2004, reiese că OG: 2/2001, nefiind lege organică, nu mai poate conține prevederi contrare Legii nr. 554/2004"; a se vedea D. C. DRAGOȘ, Legea contenciosului administrativ: comentarii şi explicații, ed. a 2-a, rev., Ed. C.H. Beck, București, 2009, p. 183. În contextul analizării aceleiași probleme ridicate în cazul O.G. nr. 2/2001, un alt autor afirmă că în această situație „actele de sancționare contravențională sunt atacabile după procedura prevăzută de Legea contenciosului administrativ”, a se vedea F. COMAN-KuND, Instanța competentă în materie contravențională în lumina prevederilor noï legi a contenciosului administrativ, în C.J. nr. 5/2005, p. 83, apud D. C. DRAgoș, op.cit., p. 183. Așa cum se arată însă, Curtea Constituțională a mers pe o interpretare mai largă și, cu ocazia analizei constituționalității textului art. 5 alin. (2), a ignorat formularea incorectă, statuând că procedura prevăzută de O.G. nr. 2/2001 este în integralitate aplicabilă, în temeiul recursului paralel; a se vedea Decizia CCR nr. 182/2006, M.of.: 366/26 aprilie 2006.

17 Potrivit art. 2 alin. (1) lit. h) din Legea nr. 554/2004: „nesoluționare în termenul legal a unei cereri - faptul de a nu răspunde solicitantului în termen de 30 de zile de la înregistrarea cererii, dacă prin lege nu se prevede alt termen”. 
2. Delegarea legislativă „comună” - Ordonanțele Guvernului

Unica situație de delegare legislativă permisă de Constituție o constituie transferul atribuției de a legifera către executivi ${ }^{18}$.

$\mathrm{Cu}$ privire la acest caz excepţional de preluare a puterii legislative de către altă autoritate, s-a pronunțat recent și Curtea Constituțională în jurisprudența sa. Sesizată fiind cu excepția de neconstituționalitate a prevederilor Legii nr. 55/2020 privind unele măsuri pentru prevenirea și combaterea efectelor pandemiei de COVID-19, Curtea a statuat în motivarea deciziei sale ${ }^{19}$ asupra delegării legislative către Guvern. Astfel, aceasta a subliniat că

\#... ordonanțele şi ordonanțele de urgență ale Guvernului, adoptate în temeiul delegării legislative, sunt acte normative care cuprind norme cu caracter primar, de domeniul legii. Astfel, într-o jurisprudență constantă, Curtea Constituțională a statuat că în ceea ce privește conceptul de «lege» (...) acesta are mai multe înțelesuri în funcție de distincția ce operează între criteriul formal sau organic și cel material. Potrivit primului criteriu, legea se caracterizează ca fiind un act al autorității legiuitoare, ea identificându-se prin organul chemat să o adopte şi prin procedura ce trebuie respectată în acest scop. (...) Criteriul material are în vedere conținutul reglementării, definindu-se în considerarea obiectului normei, respectiv a naturii relațiilor sociale reglementate. În ceea ce privește ordonanțele Guvernului, (...) elaborând astfel de acte normative,

18 Definind această limitare a suveranității Parlamentului în materia legiferării, Curtea Constituțională a României a statuat că ea „își găsește o justificare unanim acceptată ce izvorăște din principiul separației și al colaborării puterilor în stat”, Decizia nr. 1438 din 4 noiembrie 2010 referitoare la excepția de neconstituționalitate a dispozițiilor art. 17 lit. c) din Legea nr. 78/200o pentru prevenirea, descoperirea și sancționarea faptelor de corupție, precum și a dispozițiilor Ordonanței de urgență a Guvernului nr. 124/2005 privind modificarea și completarea Legii nr. 78/2000 pentru prevenirea, descoperirea și sancționarea faptelor de corupție, publicată în M.of.: 16/17 ianuarie 2011.

19 Decizia nr. 45 din 25 iunie 2020, publicată în M.of.: 578/1 iulie 2020. 
organul administrativ exercită o competență prin atribuire care, prin natura ei, intră în sfera de competență legislativă a Parlamentului. Prin urmare, ordonanța nu reprezintă o lege în sens formal, ci un act administrativ de domeniul legii, asimilat acesteia prin efectele pe care le produce, respectând sub acest aspect criteriul material. În consecință, întrucât un act juridic normativ, în general, se definește atât prin formă, cât și prin conținut, legea în sens larg, deci cuprinzând și actele asimilate, este rezultatul combinării criteriului formal cu cel material (...) Ordonanțele și ordonanțele de urgență ale Guvernului, sub aspect material, conțin norme de reglementare primară, având o forță juridică asimilată cu a legii ${ }^{20}$ ".

Astfel, Constituția consacră două forme distincte ale acestei delegări: pe de o parte, ordonanțele simple ale guvernului, cu un regim constituțional „normal”, - prevăzute de art. 108 și de art. 115 alin. (1) - (3) din legea fundamentală, și, pe de altă parte, ordonanțele de urgență - al căror regim de excepție este prevăzut în alineatele (4) -(6) ale aceluiași art. 115.

În privința ordonanțelor simple, aşa cum a statuat şi doctrina ${ }^{21}$, conţinutul acestora nu poate viza sfera legilor organice, domeniul celor din urmă fiind expres și limitativ prevăzut în art. 73 alin. (3) din Constituție.

În adoptarea ordonanțelor de urgență, executivului îi este acordată o mai mare putere de legiferare ${ }^{22}$, existând posibilitatea unei „intruziuni” în domeniul legii organice - dar aceasta în mod cu totul excepțional și în cazuri de strictă necesitate. Referitor la posibilitatea guvernului de a interveni prin

\footnotetext{
${ }^{20}$ Argumente aduse în vedere și prin Decizia nr. 405 din 15 iunie 2016, publicată în M.of.: 517/8 iulie 2016, paragrafele 62 și 63 .

${ }^{21}$ I. Muraru, E.S. TĂNĂSEscu, D.A. Tofan, Constituția României: Comentariu pe articole, Ed. C.H. Beck, București, 2008, p. 1088.

22 Limitările prevăzute expressis verbis prin Constituție în ceea ce privește adoptarea ordonanțelor de urgență vizează legile constituționale, regimul instituţiilor fundamentale ale statului, drepturile, libertățile și îndatoririle prevăzute de Constituţie, drepturile electorale, măsurile de trecere silită a unor bunuri în proprietate publică.
} 
ordonanțe de urgență în materii ce fac obiectul legilor organice s-a pronunțat recent Curtea Constituțională, în contextul analizării excepției de neconstituționalitate a prevederilor Ordonanței de urgență a Guvernului României nr. 57/2019 privind Codul administrativ23. În acest context, prin raportare la transpunerea legislației europene în dreptul intern, curtea a arătat că

, ... instrumentul normativ prin care legislația internă transpune/se aliniază celei europene n-ar trebui să fie ordonanța de urgență a Guvernului, deoarece doar scopul armonizării în sine nu poate justifica, singur, utilizarea delegării legislative, consacrată ca mijloc secundar și excepțional de reglementare de care Guvernul poate uza numai în condițiile restrictive ale art. 115 din Constituție.” Totuși, continuându-și raționamentul, a admis, în situații de excepție, „utilizarea ordonanței de urgență a Guvernului ca instrument de legiferare pentru situații concrete, stabilind, în considerarea obligațiilor impuse statului român de art. 148 alin. (4) din Constituţie, că Guvernul este abilitat din punct de vedere constituțional ca, prin mijloacele pe care le are la îndemână, să garanteze îndeplinirea obligațiilor României față de Uniunea Europeană”. Curtea a subliniat însă că „urgența reglementării apare atunci când o situație extraordinară - care se abate semnificativ de la obișnuit - este preexistentă urgenței, este cuantificabilă și obiectivă”.

Se poate observa astfel că unica situație în care norma fundamentală permite delegarea legislativă este aceea a ordonanțelor guvernului, neexistând nici în acest caz o putere absolută de legiferare. În privința ordonanțelor simple, Constituția prevede expres imposibilitatea alterării domeniului legilor organice, în timp ce în privința ordonanțelor de urgență se

23 Decizia nr. 60/2020 de respingere a excepției de neconstituţionalitate a prevederilor Ordonanței de urgență a Guvernului nr. 57/2019 privind Codul administrativ, publicată în M.of.: 369/8 mai 2020. 
recunoaște o oarecare atenuare a acestei reguli, care nu poate însă conduce la o deturnare a scopului pentru care ea a fost permisă.

\section{Delegarea legislativă „improprie”}

Situațiile în care o prevedere legală conferă unui organ administrativ puterea de a reglementa în domenii care fac obiectul exclusiv al legii organice au fost supuse de-a lungul timpului analizei Curţii Constituționale a României, ajungându-se la o concluzie firească: unica situație de delegare legislativă acceptată o constituie ordonanțele guvernului. Orice alt act normativ, chiar emis de Guvernul României, este neconstituțional în măsura în care tinde să altereze legea organică.

În acest sens, prin Decizia nr. 818/7 decembrie 2017²4, instanța de control constituțional a admis excepția de neconstituţionalitate ridicată, constatând că dispozițiile art. 69 alin. (5) din Legea nr. 188/1999 privind Statutul funcționarilor publici sunt neconstituționale. Situația adusă în fața instanței viza transmiterea către puterea executivă a competenței exclusive ${ }^{25}$ a legiuitorului organic de a reglementa în domenii ce țin de statutul funcționarilor publici. Textul a cărui constituționalitate se contesta permitea ca un aspect esențial al raporturilor de serviciu ale unui funcționar public să fie reglementat prin act administrativ, ce are caracter infralegal. Curtea a subliniat astfel că

„... delegarea atribuției de a stabili aceste norme către Guvern prin emiterea unor acte administrative cu caracter normativ, de rang infralegal, nu respectă exigențele principiului constituţional al

\footnotetext{
24 Publicată în M. Of. nr. 311/10 aprilie 2018.

25 Potrivit art. 61 din Constituția României: „(1) Parlamentul este organul reprezentativ suprem al poporului român și unica autoritate legiuitoare a țării [...]”.
} 
securităţii juridice, în componenta sa referitoare la calitatea legii”. Aceasta a mai reținut și „o încălcare a dispozițiilor art. 1 alin. (4) din Constituţie referitor la principiul separației și echilibrului puterilor în stat, prin delegarea unei atribuții ce aparține în exclusivitate legiuitorului către Guvern"26".

O altă decizie de actualitate ${ }^{27}$ stabilește neconstituționalitatea oricărei alte modalități de delegare legislativă în afara celei prevăzute de art. 115 din Constituție. În acest sens, în contextul instituirii stării de urgență pe teritoriul României, curtea a constatat neconstituționalitatea dispozițiilor legale care au permis președintelui, prin decret (act administrativ normativ) să legifereze în perioada stării de urgență, afirmând că

\#... dacă legiuitorul constituant ar fi considerat că prin decret, ca act administrativ normativ, Președintele, ca autoritate executivă, poate adopta norme cu putere de lege în perioada stării de urgență sau de asediu, ar fi prevăzut în mod expres această delegare legislativă, aşa cum a reglementat prin art. 115 în cazul autorității executive a Guvernului (...) Continuitatea în plan legislativ a Parlamentului asigură luarea măsurilor excepționale impuse de situația de criză, în condițiile în care restrângerea drepturilor și a libertăților nu se poate realiza decât prin lege, astfel cum rezultă din interpretarea coroborată a dispozițiilor art. 53 și ale art. 115 alin. (6) din Constituție. Astfel, norma constituțională constituie o garanție împotriva eventualelor

${ }^{26}$ Printr-o recentă decizie pronunțată în data de 8 octombrie 2020, Curtea Constituțională a decis, cu unanimitate de voturi, că sunt neconstituționale dispozițiile articolului 79 alin. (5) din Legea privind Statutul funcționarilor publici. Este vorba despre prevederea potrivit căreia modul în care sunt constituite comisiile de disciplină este stabilit prin hotărâre de Guvern, la propunerea Agenției Naționale a Funcționarilor Publici. A se vedea CCR, dec.: 737/8-10-2020, publicată în M.of.: 1189/7 decembrie 2020.

27 Decizia nr. 152/2020 referitoare la excepția de neconstituționalitate a dispozițiilor art. 9, art. 14 lit. c $^{1}$ )-f) și ale art. 28 din Ordonanța de urgență a Guvernului nr. 1/1999 privind regimul stării de asediu și regimul stării de urgență și a ordonanței de urgență, în ansamblul său, precum şi a Ordonanței de urgență a Guvernului nr. 34/2020 pentru modificarea şi completarea Ordonanței de urgență a Guvernului nr. 1/1999 privind regimul stării de asediu și regimul stării de urgență, în ansamblul său, publicată în M.of.: 387 din 13 mai 2020. 
excese sau abuzuri ale autorităților publice executive, Parlamentul, ca organ reprezentativ suprem al poporului, acționând ca un garant al drepturilor și al libertăților cetățenilor. În al treilea rând, existența unei stări de asediu sau de urgență se încadrează per se în ipoteza de incidență a prevederilor art. 115 alin. (4) din Constituție, care permit Guvernului să adopte ordonanțe de urgență «numai în situații extraordinare». Așa fiind, inclusiv legiuitorul delegat are abilitarea constituțională să intervină cu celeritate și să modifice cadrul legislativ existent, adoptând măsurile normative pe care starea de fapt le impune. În concluzie, cadrul constituțional în vigoare delimitează în mod riguros competențele autorităților publice, respectiv partajarea atribuțiilor legislative de cele executive, excepția de la regulă fiind în mod expres reglementată și de strictă interpretare (...) Curtea constată că atribuția constituțională și legală privind instituirea stării de urgență poate fi exercitată de Președintele României doar în cadrul constituțional menționat şi doar cu respectarea prevederilor legale la care Constituția face trimitere prin coroborarea art. 93 alin. (1) cu art. 73 alin. (3) lit. g), respectiv legea organică privind regimul stării de asediu și al stării de urgență.”

Așa cum în mod corect a statuat instanța de control constituțional în jurisprudența sa, singura excepție de la suveranitatea parlamentului în exercitarea puterii legislative este constituită de ordonanțele guvernului. Or, în măsura în care nici măcar autoritatea căreia îi este recunoscută delegarea legislativă prin Constituție nu poate reglementa peste lege prin acte administrative normative, cu atât mai mult apare ca neconstituţional transferul de competență legislativă în sarcina unui alt organ administrativ. 


\section{B. Delegarea legislativă și cariera magistraților}

1. Incidența regulilor de contencios administrativ în ceea ce privește cariera magistraților

Așa cum am arătat, Consiliul Superior al Magistraturii este organul administrativ cu atribuții recunoscute de lege în materia carierei magistraților, având competența de a adopta acte administrative normative și de a reglementa proceduri specifice. În consecință, aplicabilitatea normelor de contencios administrativ în acest domeniu nu poate fi negată; prin urmare, potrivit regulii prevăzute de legea organică în materie de contencios administrativ, termenul de care administrația dispune pentru a răspunde cererii particularului este acela de 30 de zile.

O regulă nu exclude însă existența unor excepții. Tocmai de la această premisă pleacă instanța supremă în interpretarea pe care o dă speței, afirmând că legile organice în materia carierei magistraților (Legea nr. 303/2004 privind statutul judecătorilor și al procurorilor și Legea nr. 317/2004 privind Consiliul Superior al Magistraturii) ar permite unui organ de natură administrativă să adopte hotărâri care instituie excepții de la regula prescrisă de Legea nr. 554/2004. Este invocat astfel transferul puterii de „legiferare 28 ” în acest domeniu către CSM.

Or, dacă am accepta un astfel de raționament, am ajunge inevitabil să ne întrebăm dacă „delegarea” în cauză nu constituie o modalitate de a sustrage de la aplicarea legii organice materii care ar intra prin excelență în raza ei de

${ }^{28}$ A delega unui organ administrativ competența de a decide în materia carierei magistraților implică transmiterea chiar a puterii de legiferare.

61 
aplicare și, totodată, o încălcare a principiilor separației puterilor în stat şi securităţii raporturilor juridice.

\section{Interdicția expresă de a adăuga la lege}

Regulamentul de organizare și desfășurare a concursului de promovare a judecătorilor și procurorilor constituie un act administrativ normativ, având o aplicabilitate generală, asupra unui număr nedeterminat de persoane, având ca obiect modificarea ordonanțării juridice generale ${ }^{29}$. În măsura în care un astfel de act tinde să stabilească prin conținutul său norme de contencios administrativ, se impune analiza (în scopul soluționării) „conflictului de reglementări” în raport cu Legea nr. 554/2004.

Potrivit raționamentului instanței supreme în speța de faţă, chiar Legea contenciosului administrativ ar permite ca, prin legi speciale, să se deroge de la termenul general de 30 de zile. Totodată, înalta curte consideră că noțiunea de „legi speciale” folosită în cuprinsul Legii nr. 554/2004 nu ar trebui interpretată limitativ, ci ar cuprinde atât legile organice, cât și legile ordinare, dar şi „legea în sens larg”, cum ar fi un act administrativ normativ. Aceasta adaugă şi că Legea nr. 317/2004 a permis consiliului să adopte regulamente și hotărâri în materia promovării judecătorilor și procurorilor.

Însă, trebuie să ținem cont de faptul că un regulament adoptat prin Hotărâre a Plenului Consiliului Superior al Magistraturii nu echivalează, ca forţă juridică, cu o lege organică. Dacă un astfel de regulament tinde să reglementeze domenii care fac obiect exclusiv al legii organice acesta încalcă prevederile constituționale. Mai mult, chiar în măsura în care nu ar urmări să

29 Ov. Podaru, Drept administrativ. Vol. I - Actul administrativ, ( I) Repere pentru o teorie altfel, Ed. Hamangiu, București, 2010, p. 61.

\section{2}


legifereze în acest domeniu și ar adopta un act propriu, CSM oricum nu ar putea deroga de la legea organică. De vreme ce, așa cum am arătat, contenciosul administrativ - domeniu rezervat legilor organice - nu poate fi reglementat nici măcar prin legi ordinare, cu atât mai puțin un act administrativ normativ ar putea interveni și altera acest domeniu330.

Totodată, interpretarea conformă legii fundamentale este aceea potrivit căreia noțiunea de „legi speciale” include strict legile organice, ordinare sau constituționale. Un raționament distinct - cum este cel motivat de înalta curte - încalcă prevederile constituţionale, conducând la o inversare forțată a piramidei normelor juridice. Iar acceptarea unei asemenea interpretări nu ar face decât să pună la dispoziția CSM o modalitate de a ocoli dispozițiile instituite chiar prin legea organică prin care se reglementează organizarea acesteia, cu justificarea unei nelegale „delegări de putere legislativă”.

În ceea ce privește competența Consiliului Superior al Magistraturii de a adopta regulamente şi hotărâri în materia promovării judecătorilor și procurorilor, chiar Legea nr. 317/2004 stabilește imperativ, în art. 38 alin. (7), că „Plenul Consiliului nu va putea adopta Regulamente sau hotărâri prin care să adauge la dispozițiile cuprinse în legi, pe motiv că acestea ar fi neclare sau incomplete."

Or, în măsura în care acestui organ administrativ nu îi este permis să adauge la legile neclare sau incomplete, a fortiori nu este permis să facă acest lucru acolo unde legea este clară și completă, cum este şi cazul în speța de față.

30 Pentru o privire mai detaliată a poziției pe care actul administrativ normativ o ocupă în ierarhia normelor, a se vedea C-A. GHERGHINĂ, Legalitatea actului administrativ normativ în statul de drept, Ed. Universul Juridic, București, 2019, p. 28 și urm.

\section{3}


3. Mecanismul de apreciere, de către instanța de judecată, a legalității unui act administrativ normativ adoptat de CSM

a) Două modalități inadecvate: excepția de neconstituționalitate și exceptia de nelegalitate

Dezvoltând ideea potrivit căreia competența CSM în stabilirea procedurilor și a termenelor pentru promovarea în funcţie a magistraţilor își are fundamentul în Legea nr. 371/2004, Înalta Curte afirmă în final că „de altfel, în speță nu a fost invocată nicio excepție de neconstituționalitate sau nelegalitate cu privire la textele incidente”. Or, dacă am analiza aceste soluții propuse, plecând de la ceea ce este evident - hotărârile Consiliului Superior al Magistraturii constituie acte administrative normative - nu putem decât să ne îndoim de eficacitatea soluțiilor sugerate de instanța supremă.

Astfel, pe de o parte, ridicarea excepției de neconstituţionalitate nu era utilă în speța de fațăa ${ }^{31}$, iar pe de altă parte, aceste hotărâri în materia carierei magistraților nu pot face obiectul unei excepții de neconstituționalitate, pentru că în acest caz instanța de contencios constituțional este chemată să verifice ex post compatibilitatea unei legi sau ordonanțe ori a unei/unor dispoziții dintr-o lege sau dintr-o ordonanță, cu prevederile și principiile de

$3^{1} \mathrm{Nu}$ numai că ridicarea excepției de neconstituționalitate se dovedeşte inutilă, dar mai mult, această soluție pusă la dispoziție de instanța supremă nu este efectivă, în speță petentul neavând motive pentru a se folosi de ea, având în vedere că textul potențial vătămător se regăsește într-un act administrativ normativ. În mod cert excepția de neconstituționalitate putea fi ridicată cu privire la legea organică ce permite CSM adoptarea unor Regulamente care intră în conflict cu alte legi organice, însă într-o speță precum cea de față ar fi putut exista riscul ca particularul să își creeze o situație chiar mai rea, putând pierde chiar șansa de a promova, de vreme ce inclusiv vocația sa de a ocupa postul în cauză, strâns legată de termenul de 3 luni, era reglementată prin același regulament. 
ordin constituțional. Or, nu poate fi pus semnul egalității între un act administrativ normativ și o lege sau ordonanță.

Pe de altă parte, hotărârile Consiliului Superior al Magistraturii nu pot face nici obiectul excepției de nelegalitate, căci, potrivit art. 4 alin. (1) din Legea nr. 554/2004 a contenciosului administrativ, mecanismul acestei excepţii vizează să verifice exclusiv „legalitatea unui act administrativ unilateral cu caracter individual".

b) $\quad$ o propunere îndrăzneață: înlăturarea normei cu forță juridică inferioară

În măsura existenței unei situații în care un act administrativ normativ ar tinde să devină un instrument de reglementare în domeniul contenciosului administrativ, intrând în conflict cu legea organică, trebuie să se dea prevalență normei cu forță juridică superioară.

Aplicarea exclusivă a Legii nr. 554/2004 în raport cu un act administrativ normativ care tinde prin conținut la reglementarea contenciosului administrativ este susținută şi de principiul ierarhiei normelor juridice. Este unanim acceptat că, în cadrul „blocului de legalitate”, locul imediat inferior Constituției îl ocupă legile, în sens de acte de reglementare primară având ca emitent parlamentul. Actele administrative normative au în schimb caracter infralegal, Legea nr. 24/200o privind normele de tehnică legislativă pentru elaborarea actelor normative ${ }^{32}$ prevăzând în art. 4 alin. (3) că „actele normative date în executarea legilor, ordonanțelor sau a hotărârilor Guvernului se emit în limitele și potrivit normelor care le ordonă."

32 Publicată în M.of: 260/21 aprilie 2010. 
Totodată, este important de subliniat că recunoașterea poziției superioare pe care legea o ocupă în ierarhia normelor se impune şi celor desemnaţi să o aplice situațiilor conflictuale concrete, în conformitate cu art. 124 alin. (3) din Constituție, potrivit căruia „Judecătorii sunt independenți și se supun numai legii."

Principiul arătat se impune cu și mai multă putere în situații precum cea din speță, când un regulament - act administrativ normativ - aduce atingere drepturilor particularilor. În această privință, doctrina a statuat în sensul inaplicabilităţii unui act administrativ normativ în ipoteza în care acesta ar fi mai puțin favorabil decât legea pe care o aplică, pentru că acesta instituie, în esență, o limitare, o condiționare 33 .

Așadar, având în față un act administrativ normativ și o lege, ambele instituind proceduri clare, judecătorul nu poate ignora legea dând prevalență unui act administrativ normativ ce instituie limitări (căruia, astfel, i s-ar „supune”). Numai aplicând cu prioritate legea acesta poate asigura respectarea principiului ierarhiei normelor juridice ${ }^{34}$.

33 Ov. Podaru , Drept administrativ. Vol. I - Actul administrativ..., op.cit., p. 227.

34 În acest sens se pronunță și doctrina, statuând că „instanțelor de judecată ar trebui să li se recunoască prerogativa de a face aplicarea principiului ierarhiei forței juridice a actelor normative și de a înlătura din proces normele administrative contrare unor dispoziții cu forță juridică superioară, chiar în lipsa unei acțiuni directe în anulare îndreptate împotriva actului administrativ normativ respectiv”. Se recunoaște în acest fel o reală „putere” a instanței de a aplica cu prioritate legea, chiar și în ipoteza în care particularul nu a solicitat anularea actului administrativ care încalcă această lege; a se vedea G. BoGASIU, Legea contenciosului administrativ comentată și adnotată: cuprinde legislație, jurisprudență și doctrină, ed. a 4a, rev., Ed. Universul Juridic, București, 2018, p. 176. Aceeași prioritate a legii în raport de actele administrative normative este subliniată și de alți autori. $\mathrm{Cu}$ referire la art. 4 din Ordonanța Guvernului 2/2001 care prevede în art. (1), (2) termenele pentru intrarea în vigoare a dispozițiilor din acte normative prin care se stabilesc și se sancționează contravențiile (regula de 30 de zile și excepția de 10 zile), s-a afirmat în doctrină faptul că aceste termene se aplică 
În concluzie, observăm că problema conflictului act administrativ normativ - lege organică (admițând că în speță ar exista un asemenea conflict) a fost tranşată de către instanța supremă într-o manieră cel puțin criticabilă. Astfel, pe de o parte, modalitatea de apreciere a legalităţii actului administrativ sugerată petentului se dovedește inadecvată. Pe de alta, aşa cum am arătat, faptul că Înalta Curte dă prevalență actului cu caracter infralegal în ipoteza unei contradicții între acesta și legea organică ridică serioase probleme privind respectarea principiului constituţional al ierarhiei normelor juridice și conduce practic la o inversare a acestei ierarhii.

numai actelor administrative normative. Aceasta deoarece ordonanța are forța juridică a unei legi ordinare; , în consecință dacă o altă ordonanță sau o lege ar stabili un termen mai scurt, el s-ar aplica în mod evident”. Aceeași autori arată că „nu ar fi însă o surpriză ca, la cererea celui interesat, Curtea Constituțională să declare un termen mai scurt de 30/10 zile ca fiind neconstituțional, raportat la prevederile art. 1 alin. (5) din Legea fundamentală (principiul respectării legilor), pentru același raționament pentru care, într-o vastă jurisprudență, Curtea a declarat neconstituţionale toate reglementările «speciale» care «deroga» de la (mai exact nu respectau) prevederile generale ale Legii nr. 24/2000 privind normele de tehnică legislativă pentru elaborarea actelor normative”. Se subliniază totodată că „(..) raportat la art. 1 alin. (5) din Constituție(...) stabilirea termenului minim în care un act de reglementare contravențională intră în vigoare este de competența legiuitorului, şi nu a administrației publice. Prin urmare, atunci când un organ administrativ ar stabili el însuşi un termen mai scurt decât cel legal, ar încălca prevederea constituțională amintită. Pe de altă parte, atunci când judecătorul, făcând parte din cea de-a treia putere în stat, aceea neimplicată în «conflict», trebuie să tranșeze lucrurile, el are de partea sa prevederile art. 124 alin. (3) din Constituție potrivit cărora «Judecătorii sunt independenți și se supun numai legii». Prin urmare, atunci când judecătorul sesizat cu plângere contravențională este pus în situația delicată de a alege între două texte normative suficient de clare încât să pară că ambele dobândesc aplicabilitate, dintre care unul are forța juridică a legii, iar celălalt este act administrativ, unul și același text constituțional îi permite (și, totodată, îl obligă) să dea prevalență textului de lege (...)”; a se vedea O. PodAru, R. CHIRIȚĂ, I. PĂSCULEȚ, Regimul juridic al contravențiilor; O.G. nr. 2/20O1 comentată, ed. a 4-a, Ed. Hamangiu, București, 2019, p. 66 și urm.

\section{7}


II. Natura termenului de 90 de zile de valorificare a rezultatelor concursului

Aşadar, art. 30 alin. (1) din Regulamentul Consiliului Superior al Magistraturii 35 stabilește un termen de 90 de zile în care cel care a fost declarat admis, fără însă a ocupa un loc dintre cele pentru care a concurat, trebuie să își valorifice rezultatele concursului. Făcând abstracție de problemele privind legalitatea unui asemenea regulament, trebuie să analizăm care sunt raporturile dintre acest termen și cele reglementate de Legea nr. 554/2004 a contenciosului administrativ. Tocmai de aceea, vom trata mai întâi problema abstractă a termenelor în general (I), urmând să ne îndreptăm atenția spre problema termenului de 90 de zile prevăzut în Regulamentul amintit (II).

\section{A. Despre termene în general și posibilele lor clasificări}

1. Drepturile subiective și termenele care le afectează existența sau, după caz, eficacitatea

Un drept subiectiv este indisolubil legat de perioada sa limitată de manifestare, sau, din contră de imprescriptibilitatea sa. Fiecărei categorii de drepturi îi poate fi asociată, totodată, o modalitate specifică de stingere.

35 Acest Regulament a fost aprobat prin Hotărârea nr. 621/2006 pentru aprobarea Regulamentului privind organizarea și desfășurarea concursului de promovare a judecătorilor şi procurorilor, publicată în M.of.: 825/6 octombrie 2006, fiind modificat prin Hotărârea nr. 799/2012 pentru modificarea Regulamentului privind organizarea și desfăşurarea concursului de promovare a judecătorilor și procurorilor, aprobat prin Hotărârea Plenului Consiliului Superior al Magistraturii nr. 621/2006, publicată în M.of.: 698/11 octombrie 2012. 


\section{a) Drepturile reale și uzucapiunea}

Drepturile reale - ius in re - sunt definite ca fiind acele drepturi subiective patrimoniale în temeiul cărora titularul lor poate să exercite anumite puteri, prerogative asupra unui bun determinat, în mod direct și nemijlocit, fără intervenția altei persoane ${ }^{36}$.

Referitor la durata acestor drepturi, doctrina s-a pronunțat în sensul că singurul drept real perpetuu este dreptul de proprietate37. Durata celorlalte drepturi reale principale este legată fie de durata dreptului de proprietate, fie de persoana titularului lor (uzufructul, uzul și abitația sunt viagere când titularul lor este o persoană fizică sau au o durată limitată în timp la cel mult 30 de ani când titularul lor este o persoană juridică). Durata drepturilor reale accesorii este însă legată de durata drepturilor de creanță pe care le garantează $\breve{3}^{38}$.

Regula în materia drepturilor reale o constituie caracterul perpetuu, imposibilitatea stingerii lor prin neuz ${ }^{39}$. În acest sens, art. 562 C.civ prevede

${ }^{36}$ C. BîRsAn, Drept civil: drepturi reale principale, ed. a 3 -a, rev., Ed. Hamangiu, București, 2017, p. 23.

37 S-a remarcat însă că există şi cazuri de excepție când proprietatea are un caracter temporar, cum este de pildă, dreptul de proprietate asupra creației intelectuale, a se vedea I. SFERDIAN, Drept civil. Drepturi reale principale, Ed. Hamangiu, 2013, p. 85. În acest caz, dreptul de proprietate are o durată limitată în timp, fiind afectat de un termen extinctiv. Menționăm însă că dreptul de proprietate intelectuală are o semnificație distinctă de dreptul real de proprietate. $3^{8}$ V. STоіса, Drept civil: drepturi reale principale, ed. a 3-a, Ed. C.H.Beck, București, 2017, p.35. Autorul arată că această durată mai mare a drepturilor reale principale în comparație cu drepturile de creanță este legată și de ideea de posesie, atât ca element de drept, cât și ca stare de fapt. Astfel, „drepturile de creanță nu au atributul posesiei și, cu excepția celor care se încorporează în substanța titlului, nu sunt susceptibile de a fi posedate”.

39 Precizăm însă că există situații în care neuzul constituie chiar o modalitate de stingere a dreptului real. Astfel, în materia dezmembrămintelor dreptului de proprietate privată, dreptul de uzufruct se stinge prin neuzul timp de 10 ani sau timp de 2 ani dacă este vorba de uzufructul

\section{9}


că „(1) Dreptul de proprietate privată se stinge prin pieirea bunului, dar nu se stinge prin neuz. El poate fi dobândit de altul prin uzucapiune sau într-un alt mod, în cazurile și condițiile determinate de lege. (2) Proprietarul poate abandona bunul său mobil sau poate renunța, prin declarație autentică, la dreptul de proprietate asupra bunului imobil, înscris în cartea funciară (...)”. Existența dreptului real nu este condiționată de exercitarea neîntreruptă a acestuia.

Totuși, chiar și în materia drepturilor reale există situații în care pasivitatea titularului dreptului este învinsă și asistăm la o limitare a perpetuității sale. Instituția uzucapiunii (prescripția achizitivă) este introdusă tocmai pentru a sancționa fostul proprietar neglijent, care prin pasivitate și dezinteres a abandonat bunul său în mâna altei persoane care sa comportat public ca titular al dreptului de proprietate ${ }^{40}$. Atât în materie imobiliară ${ }^{41}$, cât și în materie mobiliară ${ }^{42}$, uzucapiunea constituie unul dintre cele mai importante efecte ale posesiei când aceasta se prelungește în timp și

unei creanțe, în conformitate cu art. 746 alin. (1) lit. e) C.civ. Și în materia dreptului de servitute se prevede stingerea acestuia prin neuzul timp de 10 ani, potrivit art. 770 alin. (1) lit. f) C.civ.

$4^{\circ}$ I. SFERDIAN, op.cit., p. 411.

${ }^{41}$ Uzucapiunea imobiliară reunește două ipoteze de dobândire a proprietății ca efect al posesiei. Prima este uzucapiunea extratabulară, reglementată de art. 930 C.civ, ce presupune alături de condiția unei posesii timp de 10 ani și alte condiții alternative - cerința ca proprietarul înscris în cartea funciară să fi decedat sau, după caz, să își fi încetat existența, cerința ca în cartea funciară să fi fost înscrisă o declarație de renunțare la proprietate sau ca imobilul să nu fi fost înscris în nicio carte funciară - și, în plus, cerința înregistrării cererii de înscriere înainte ca o altă persoană să își înscrie în mod legitim propriul drept. A doua ipoteză de uzucapiune imobiliară este cea tabulară, situație în care persoana care invocă prescripția achizitivă a fost înscrisă cu bună-credință în cartea funciară și a posedat bunul timp de 5 ani după momentul înregistrării cererii de înscriere.

42 Uzucapiunea mobiliară implică, potrivit art. 939 C.civ., exercitarea posesiei pentru o perioadă de 10 ani și neîndeplinirea condițiilor pentru a opera dobândirea proprietății mobiliare prin posesia de bună-credință. 
totodată, conduce practic la o diminuare a caracterului perpetuu de care se bucură drepturile reale 43 .

Durata îndelungată de existență a drepturilor reale sau chiar perpetuitatea acestora are implicații și în planul termenelor de prescripție, drepturile reale fiind fie imprescriptibile (dreptul de proprietate), fie prescriptibile în termene mai lungi, regula fiind instituită de norma regăsită la art. 2518 alin. (2) C.civ.

\section{b) Drepturile de creanță. Prescripția extinctivă}

Drepturile de creanță - ius ad personam - au fost consacrate ca fiind drepturile patrimoniale în temeiul căruia subiectul activ, denumit creditor, poate pretinde subiectului pasiv, denumit debitor, să dea, să facă sau să nu facă o anumită prestație la care acesta din urmă ar fi fost îndreptățit în lipsa angajamentului juridic44.

Drepturile de creanţă se sting prin îndestularea creanței, concomitent cu stingerea obligației corelative acestei creanțe. Constituind elemente ale raportului obligațional ${ }^{45}$, acestea au o durată mai scurtă decât drepturile reale principale, consecință firească a naturii lor personale.

43 În ceea ce priveşte însă proprietatea publică, doctrina a subliniat faptul că imprescriptibilitatea are valoare constituţională, ca o consecință directă a inalienabilității, prevăzută expres la art. 136 alin. (4) din Constituție. Astfel, „din faptul imprescriptibilității și inalienabilității domeniului public rezultă în mod imperativ concluzia că nicio posesie utilă nu poate fi opusă de către particular liberei dispoziții pe care autoritatea domenială o exercită asupra unui element al acestui domeniu”, a se vedea Ov. PODARU, Drept administrativ. Vol. II. Dreptul administrativ al bunurilor, Ed. Hamangiu, București, 2010, p. 74.

44 V. STOICA, op.cit., p. 31; în acelaşi sens, a se vedea G. Boroi, C.A. ANGHELESCU, Curs de drept civil: partea generală, ed. a 2-a, Ed. Hamangiu, București, 2012, p. 58.

45 Termenul de raport obligațional evocă natura relațională a oricărei datorii sau creanțe; în acest sens, a se vedea P. VAsIlescu, Drept civil. Obligații, Ed. Hamangiu, București, 2012, p. 2. 
Tot prin comparație cu drepturile reale principale, drepturile de creanță sunt, ca regulă, prescriptibile. Instituția prescripției ${ }^{46}$ nu afectează însă existența dreptului subiectiv în sine, ci mai degrabă eficacitatea acestuia și posibilitatea de valorificare a sa în fața instanței de judecată. În acest sens, în doctrină a fost stabilită distincția drept subiectiv civil - drept material la acțiune corelativ dreptului subiectiv civil, concluzia fiind aceea că ceea ce se stinge prin prescripție este doar dreptul material la acțiune ${ }^{47}$, şi nu dreptul

Același autor descrie obligația civilă ca fiind simultan un drept și o datorie, fiecare dintre aceștia având titulari distincți: subiecții raportului de obligație. Autorul analizează însă caracterul redundant și originea ideologică a conceptului de „raport juridic” în dreptul român în: Paul VASIlESCU, Raportul de drept civil - mostră de nostalgie ideologică analitică, în Studia Universitatis Babeș-Bolyai Iurisprudentia nr. 1/2020, p. 5. https://doi.org/10.24193/SUBBiur.65(2020).1.1.

46 Pentru a interveni prescripția extinctivă este necesară simpla inacțiune a titularului dreptului, într-un interval de timp suficient de lung care să justifice exonerarea de răspundere a subiectului pasiv al raportului obligațional. A se vedea M. NiCOLAE, Tratat de prescripție extinctivă, Ed. Universul Juridic, București, 2010, p. 15.

$47 \mathrm{Cu}$ referire la dreptul la acţiune, în doctrină s-a afirmat că acesta „este un drept subiectiv autonom, un drept fundamental procesual-civil, care, în pofida împrumutării caracteristicilor dreptului subiectiv substanțial, nu-și pierde astfel individualitatea proprie (...)"; a se vedea I. DELEANU, Observații cu privire la criteriul valoric de determinare a competenței de atribuțiune a instanțelor judecătorești în cazul unor categorii de acțiuni, în RRDP nr. 6/2008, p. 61 apud M .NICOLAE, Tratat de prescripție extinctivă..., op.cit., p. 194. Alți autori au susținut teza dualistă în privința dreptului la acțiune, făcând distincția drept material la acțiune - drept procesual la acțiune și subliniind că ceea ce se stinge în urma prescripției este doar dreptul material la acțiune; a se vedea M. NICOLAE, Tratat de prescripţie extinctivă..., op.cit., p. 197. Ideea este susținută și la nivel legislativ, art. 2500 alin. (1) C.civ. prevăzând expres această consecință a intervenirii prescripției extinctive. Dreptul procesual la acţiune a fost înțeles ca fiind dreptul de a accede liber la justiție, constând în facultatea sau posibilitatea acesteia de a sesiza instanța și de a pretinde judecătorului de a se pronunța asupra cererii sale, fără însă de a o și rezolva favorabil, chestiune care ține de fondul dreptului; a se vedea T. DrăGANU, Considerații critice cu privire la caracterul absolut atribuit dreptului la liber acces la justiție de Legea de revizuire a Constituției din 21 noiembrie 2003, în PR nr. 4/2004, VI, p. 117, apud M. NiCOLAE, Tratat de prescripție extinctivă..., op.cit., p. 200. 
subiectiv ${ }^{48}$. Urmare a intervenirii prescripției, acest drept este însă privat de mijlocul său de ocrotire, devenind un drept imperfect. Una dintre consecințele supraviețuirii dreptului subiectiv civil și a obligației corelative acestuia o reprezintă, aşa cum prevede art. 2506 alin. (2) C.civ, faptul că „după împlinirea termenului de prescripție, cel obligat poate să refuze executarea prestațiilor”. Mai mult, faptul că cel care a executat de bunăvoie obligația după ce termenul de prescripție s-a împlinit nu are dreptul să ceară restituirea prestației este o altă consecință ce decurge în mod nemijlocit din supraviețuirea dreptului subiectiv.

Astfel, chiar existând instituția prescripției, observăm că ea nu este de natură să afecteze dreptul de creanță în substanța sa, lipsindu-l doar de o protecție efectivă pe cale de acțiune.

\section{c) Drepturile potestative. Termenul extinctiv. Decăderea substanțială}

Drepturile potestative presupun exerciţiul direct al unor prerogative asupra unei situații juridice. Așa cum s-a remarcat49, „obiectul dreptului potestativ nu este un bun, ca în cazul drepturilor reale, nu este nici o prestație a debitorului, ca în cazul drepturilor de creanță, ci este situația juridică, un complex de drepturi şi obligații, care aparțin uneia sau mai multor persoane care vor fi influențate în mod direct de modul în care titularul dreptului potestativ îşi exercită acest drept”. Încercându-se realizarea unei clasificări a acestor drepturi după efectele juridice produse, s-au conturat trei posibile drepturi potestative: drepturile potestative constitutive - cele prin a căror

48 Ș. Diaconescu, I. Reghini, P. VAsilescu, Introducere în dreptul civil, Ed. Hamangiu, București, 2013, p. 703.

49 I. SFERDIAN, op.cit., p. 90. 
exercitare ia naștere un nou drept în patrimoniul titularului $5^{\circ}$, drepturile potestative modificatoare - prin care se schimbă o situație juridică ${ }^{51}$ și drepturile potestative extinctive, care fie pun capăt unei situații juridice pentru viitor, fie desființează retroactiv o anumită situație juridică.

Drepturile potestative constitutive prezintă însemnătate în prezentul demers tocmai pentru că implică succesiunea temporală „vocație drept subiectiv". Odată manifestată voința titularului, are loc o transformare a vocației în drept, susceptibil la rândul său de a fi supus unor termene de decădere substanțială.

Aceste drepturi, marcând puterea titularului lor de a influența o situație juridică preexistentă, sunt, ca regulă, imprescriptibile. Pentru a nu fi periclitată securitatea raporturilor juridice, ele pot fi afectate în cazuri anume prevăzute de lege de termene de decădere, în interiorul cărora acestea trebuie exercitate $^{52}$. În măsura neexercitării lor în termenul instituit în mod imperativ, ele se sting, ca efect al decăderii substanțiale.

Acest tip de decădere este incident numai dacă putem identifica un drept subiectiv care mai înainte, sau chiar independent de declanşarea oricărei proceduri (pre)judiciare este afectat în chiar ființa sa, un drept

$5^{0}$ Exemplele oferite în doctrină au fost dreptul de a dobândi coproprietatea asupra zidului comun, dreptul de a stabili servituți, dreptul de a accepta sau nu o succesiune, dreptul convențional de preferință, etc., a se vedea I. SFERDIAN, op.cit., p. 92.

${ }^{51}$ Precum ar fi dreptul de grănițuire, dreptul de a cere reducțiunea donațiilor.

$5^{2}$ Un exemplu în acest sens îl constituie dreptul de opțiune succesorală, care, potrivit art. 1103 alin. (1) C.civ. trebuie exercitat înăuntrul unui termen de 1 an, calculat de la diferite momente. Referitor la natura sa juridică, neprecizată expres în textul legal, în doctrină s-a ajuns la concluzia că acesta este un termen de decădere, principalul argument fiind acela că este vorba despre un drept de opțiune, care, fiind unul potestativ, nu privește un drept material la acțiune care s-ar pierde prin neexercitarea lui. Pentru detalii, a se vedea D. CHIRICĂ, Tratat de drept civil. Succesiunile şi liberalităţile, Ed. C.H. Beck, Bucureşti, 2014, p. 472. 
subiectiv care preexistă oricărui litigiu, care are însă potențialitatea de a fi valorificat pe calea justiției. Spre deosebire de prescripție, această instituție nu determină stingerea doar a dreptului material la acțiune, ci chiar a dreptului subiectiv.

Decăderea substanțială afectează acele drepturi ce există în afara oricărei proceduri, izolate de iminența unui parcurs litigios. Așa cum a statuat doctrina53 exercițiul dreptului subiectiv nu presupune în mod necesar introducerea unei acțiuni în justiție, „voința titularului în acest sens fiind în primul rând extraprocesuală” (și numai în mod excepțional dreptul subiectiv este apărat pe cale judiciară).

În doctrina noastră ${ }^{54}$, printre exemplele scutite de orice controverse ale unor termene de decădere substanțială ar fi următoarele: termenul de un an pentru revocarea donației pentru ingratitudine ${ }^{55}$, termenul de o lună pentru oferta de purgă a imobilului grevat de sarcini reale (art. 1804 C.civ. 1864), termenul de 60 de zile pentru exercitarea de către fostul proprietar a dreptului prioritar la dobândirea imobilului expropriat (art. 37 din Legea nr. 33/1994 privind exproprierea pentru cauză de utilitate publică56). În fiecare dintre aceste situații, manifestarea de voință se realizează, în principiu, extrajudiciar, printr-o cerere sau notificare.

53 Ov. PODARU, Despre prescripție și pseudo-prescripție în contenciosul administrativ, în Curierul Juridic nr. 1 /2014, p. 31.

54 M. NiCOLAE, Tratat de prescripție extinctivă..., op.cit., Ed. Universul Juridic, București, 2010, nr. 37.

55 În acest sens, a se vedea Fr. DEAK, Tratat de drept civil. Contracte speciale, ed. a III-a, actualizată și completată, Ed. Universul Juridic, București, 2001, p. 166.

56 Publicată în M.of.: 139/2 iunie 1994, republicată în temeiul art. 218 din Legea nr. 71/2011 pentru punerea în aplicare a Legii nr. 287/2009 privind Codul civil, publicată în M.of.: 409/10 iunie 2011. 
Trebuie remarcat că, în ceea ce privește exercițiul drepturilor subiective civile există și alte mecanisme de natură să instituie limitări în timp. În acest sens, exercițiul unui drept subiectiv civil poate fi afectat și de termene extinctive. Termenul extinctiv, utilizat în clasificările actelor juridice civile, amână, până la împlinirea lui, stingerea exercițiului dreptului subiectiv civil și executării obligației corelative ${ }^{57}$. Domeniul său de aplicare a fost restrâns în doctrină ${ }^{58}$ la contractele cu executare succesivă, împlinirea lui marcând stingerea pe viitor a efectelor unui asemenea act civil.

2. Actele de procedură și termenele în care trebuie îndeplinite acestea

Analiza termenelor în general nu poate fi redusă la planul dreptului substanțial, căci și actele procedurale realizate în vederea valorificării dreptului subiectiv sunt condiționate de exercițiul lor într-un anumit termen.

a) Termenele procedurale peremptorii și dilatorii

Timpul în care se derulează procesul civil este guvernat de termenele de procedură, termene supuse unor reguli stricte, cunoașterea sau, după caz, necunoaşterea acestora fiind de natură să decidă soarta întregului proces 59 . În acest sens, art. 180 alin. (1) C.proc.civ. prevede că „Termenele procedurale sunt stabilite de lege ori de instanță și reprezintă intervalul de timp în care poate fi îndeplinit un act de procedură sau în care este interzis să se îndeplinească un act de procedură”, continuând în alin. (2) - „În cazurile

57 M. NiCOLAE, Tratat de prescripție extinctivă..., op.cit., p. 151.

$5^{8}$ Ş. Diaconescu, I. Reghini, P. VASIlescu, op.cit., p. 566.

59 J. Heron, Th. LE BARs, Droit judiciaire prive, $4^{\mathrm{e}}$ ed., Montchrestien, Lextenso editions, Paris, 2010, p. 185 apud P. PAul, Despre termenele procedurale în noul Cod de procedură civilă, în RRDP, nr. 1/2015, https://sintact.ro/\#/publication/151010054, consultat în data de 1.11.2020. 
prevăzute de lege, termenul este reprezentat de data la care se îndeplinește un anumit act de procedură”. Definiția legală a termenelor procedurale surprinde principala clasificare a acestora, în funcție de caracterul lor termene peremptorii şi termene dilatorii.

Termenele peremptorii (imperative) sunt cele înăuntrul cărora trebuie efectuat un act de procedură ${ }^{60}$, iar nerespectarea acestora atrage sancţiunea specifică a decăderii procedurale. Ele instituie astfel limitări temporale ce îndeamnă la o acțiune, la ieșirea din pasivitate.

În schimb, termenele dilatorii (prohibitive) sunt cele înăuntrul cărora legea interzice să se efectueze actul de procedură ${ }^{61}$. Actul de procedură îndeplinit înaintea împlinirii termenului prohibitiv este considerat prematur, sancțiunea fiind nulitatea relativă ${ }^{62}$.

Astfel, ceea ce diferențiază în mod esențial cele două categorii de termene procedurale este tocmai conduita pretinsă în acest interval de timp: aceea de a acționa, în primul caz respectiv, aceea de a rămâne în așteptare, în cea de-a doua situație ${ }^{63}$.

60 Un exemplu ar fi termenul pentru declararea apelului sau a recursului - art. 468 alin. (1) şi art. 485 alin. (1) C.proc.civ.

${ }^{61}$ Astfel de termene prohibitive sunt termenul de o zi prevăzut de art. 732 alin. (1) C.proc.civ. privind aplicarea sechestrului asupra bunurilor debitorului, termenul de 15 zile prevăzut de art. 753 alin. (1) C.proc.civ. referitor la valorificarea bunurilor sechestrate.

62 P. PAUL, Despre termenele procedurale în noul Cod de procedură civilă, în RRDP nr. 1/2015, https://sintact.ro/\#/publication/151010054, consultat în data de 1.11.2020. Art. 185 alin. (2) C.proc.civ. sugerează această sancțiune specifică, prevăzând că „în cazul în care legea oprește îndeplinirea unui act de procedură înăuntrul unui termen, actul făcut înaintea împlinirii termenului poate fi anulat la cererea celui interesat".

63 Referitor la sancțiunea nerespectării acestor termene, un autor se exprima în sensul că „Categoriile-pereche din spațiul temporal al actelor de procedură sunt aşadar: tardivitate nulitate, prematuritate - anulabilitate. În prima situație, actul nu mai poate fi refăcut; în cea de-a doua situație, actul poate fi refăcut. Altfel spus, tardivitatea nu este, în principiu, 
Totodată, trebuie observat că raportul juridic concret este caracterizat de succesiunea „acțiune - inacțiune” iar clasificarea „termene imperative termene prohibitive" este aplicabilă în ceea ce îi privește pe toți participanții la acest raport. Așadar, un termen imperativ în care unul dintre participanți este obligat să acționeze constituie, în același timp, un termen prohibitiv în care celeilalte părți îi este impusă pasivitatea. Ca o consecință firească, unul și acelaşi termen nu poate fi pentru o singură parte în acelaşi timp imperativ şi prohibitiv.

\section{b) Decăderea procedurală - sancțiunea nerespectării termenului peremptoriu}

Decăderea procedurală intervine ori de câte ori este încălcat un termen procedural peremptoriu și absolut prin neefectuarea în interiorul acestuia a unui act de procedură. În această ipoteză, ceea ce se stinge este un drept procedural, ceea ce înseamnă că o procedură judiciară (de natură civilă) fie sa declanşat, fie este pe cale să o facă64. În doctrină au fost remarcate funcțiile importante ale acestei sancțiuni, destinate să asigure celeritatea procesului civil, - funcția preventivă (părțile fiind avertizate asupra consecințelor la care se expun în cazul nerespectării termenelor imperative) şi funcția sancționatorie (cel ce nu și-a exercitat dreptul procedural în termenul fixat de

remediabilă; prematuritatea este, în principiu, remediabilă”, a se vedea I. DELEANU, Noul Cod de procedură civilă. Comentarii pe articole. Vol I (Art. 1-621), Ed. Universul Juridic, București, 2013, p. 289.

64 În acest sens, art. 185 alin. (1) C.proc.civ. dispune că, „atunci când un drept procesual trebuie exercitat într-un anumit termen, nerespectarea acestuia atrage decăderea din exercitarea dreptului, în afară de cazul în care legea dispune altfel. Actul de procedură făcut peste termen este lovit de nulitate.”. 
lege sau de instanță pierde acest drept) ${ }^{65}$. Așa cum a remarcat doctrina, „termenul și decăderea procesuală sunt două concepte corelative: una fără cealaltă nu ar avea rațiune ${ }^{66 "}$.

Instituția decăderii în plan procesual trebuie diferențiată de cea a decăderii de drept substanțial. Aceasta pentru că, în ceea ce privește pierderea dreptului sau privarea de un drept, decăderea procedurală vizează întotdeauna un anumit drept procesual, niciodată dreptul subiectiv substanțial. Mai mult, în acest caz poate fi vorba „numai despre un drept determinat, recunoscut părții, nu de prerogative recunoscute instanței sau organelor de executare de a îndeplini anumite acte ${ }^{67}$ ".

\section{c) Termenul prefix și natura sa controversată}

Înțeles inițial ca sinonim pentru termenul de decădere sau forcluziune, termenul prefix nu a fost consacrat autonom în dreptul pozitiv. În doctrină însă acesta a fost definit ca fiind „acel termen al cărui final este cunoscut dinainte cu exactitate, pentru că nu este susceptibil de niciun incident

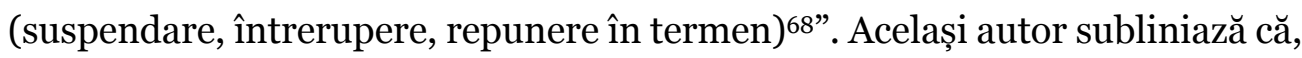
distinct față de prescripție sau decădere (fie ea substanțială sau procedurală), termenul prefix (dinainte stabilit), nu urmărește decât asigurarea supremației principiului securității raporturilor juridice.

Pentru a îț̦elege mai bine natura unui termen prefix, un exemplu ar fi acela al termenelor de sesizare a vicilor ascunse (termene de garanție),

65 G. Boroi, M. Stancu, Drept procesual civil, ed. a 5-a, rev. și adăug., Ed. Hamangiu, București, 2020, p. 387.

66 I. DELEANU, op.cit., p. 289.

67 Ibidem.

68 Ov. PODARU, Despre prescripție ..., op.cit., p.32. 
termene obiective în care trebuie să fie relevat un fapt juridic. În cazul viciilor ascunse, aceste termene au semnificația unui moment obiectiv al începutului prescripției, aplicabil în cazurile în care descoperirea viciilor ascunse nu s-a făcut anterior împlinirii lor. Dacă viciile nu au apărut înăuntrul termenului de garanție, atunci nu mai există dreptul de a solicita garanția pentru vicii, deoarece aceasta operează doar pe durata termenului de garanție. Viciile trebuie doar să se ivească înăuntrul acestor perioade de timp, nu şi să fie descoperite ${ }^{69}$. Termenele de garanție, din momentul împlinirii lor, sunt ,„̂n favoarea" celui chemat să garanteze ${ }^{70}$.

Natura acestui termen prefix este una controversată şi în dreptul francez, încercarea de definire a acestuia realizându-se doar tangențial, în trasarea liniei de demarcație între alte două instituții - prescripția şi decăderea. În acest sens, după unii autori ${ }^{71}$, termenele prefixe sunt, de regulă, termene scurte stabilite pentru a acționa în justiție, ca o condiție pusă de legiuitor pentru îndeplinirea unui act determinat, în general pentru exercitarea unei facultăți și au ca scop, nu de a sancționa neglijența celui interesat, ci de a pune capăt, în mod rapid şi în orice stare a cauzei, a posibilității de a îndeplini un act.

69 Ș. Diaconescu, I. Reghini, P. VASIlescu ..., op.cit., p. 731.

70 Astfel, dacă înăuntrul termenului legal sau convenţional de garanție, partea a descoperit viciul ascuns, atunci de la momentul descoperirii începe să curgă termenul de prescripție extinctivă; dacă însă partea nu a descoperit viciul ascuns înăuntrul termenului de garanție, deşi acesta se ivise, atunci la expirarea termenului de garanție începe să curgă automat termenul de prescripție extinctivă.

${ }^{71}$ M. Planiol, G.Ripert, J. Radouant, Traité pratique de droit civil français, VII. - Deuxième partie Obligations, Paris, Librairie générale de droit et de jurisprudence, p. 738., apud M. NicolaE, Tratat de prescripție extinctivă ..., op.cit., p. 144.

\section{0}

SUBB Iurisprudentia nr. 1/2021 
O reconsiderare la nivel conceptual a acestui termen credem că se impune pe viitor, indiferent dacă în interiorul acestuia trebuie să fie îndeplinit un act juridic sau, pur şi simplu, să se întâmple un fapt juridic obiectiv.

\section{B. Despre termenul de 90 de zile și corelarea lui cu termenele reglementate de Legea nr. 554/2004 a contenciosului administrativ}

În materia carierei magistraţilor, Regulamentul CSM prevede un termen de 90 de zile în care candidatului care nu a reușit să ocupe locul pentru care a concurat i se recunoaște vocația de a promova în funcție în măsura în care îndeplinește anumite criterii și sub condiția suspensivă a ivirii în acest termen a unui loc vacant la instanța vizată. Plecând de la logica termenelor în contenciosul administrativ, trebuie să stabilim dacă termenul intrus, cel de 90 de zile, poate coabita sau nu cu aceste termene „gazdă” şi, în cazul unui răspuns afirmativ, care este relația concretă dintre ele. 
1. Logica termenelor în contenciosul administrativ în situația refuzului nejustificat de soluționare a unei cereri72

Procedura refuzului nejustificat de a soluționa o cerere este construită în jurul a trei momente temporale distincte: trei acte de procedură necesar a fi realizate în interiorul unor termene reglementate în acest scop. Astfel, actul declanşator al mecanismelor contenciosului administrativ este cel al formulării unei cereri către administrație. Așa cum vom arăta, nu există un termen general care să îl limiteze temporal, putând fi identificate însă unele termene speciale (1). Odată formulată cererea, urmează răspunsul administrației, formulat în cele 30 de zile puse la dispoziția administrației pentru aceasta. În intervalul de 30 de zile, particularului îi este prohibit orice demers juridic (2). Ultimul moment în logica contenciosului administrativ este cel al introducerii acțiunii în contencios administrativ - posibilitate

72 În situația în care atacă un act administrativ individual nelegal, particularul are, pentru început, un termen de 30 de zile pentru a formula plângerea administrativă prealabilă [aşa cum prevede art. 7 alin. (1) din Legea nr. 554/2004 a contenciosului administrativ], doctrina pronunțându-se asupra naturii sale de termen de decădere procedural (a se vedea Ov. PODARU, Despre prescripție ..., op.cit., p. 35; I. RÂcIU, Procedura contenciosului administrativ, Ed. Hamangiu, București, 2009, nr. 224). Ulterior, administrația are la dispoziție 30 de zile pentru a răspunde acestei plângeri [prevăzut la art. 2 alin. (1) lit. h) din Legea nr. 554/2004 a contenciosului administrativ]. În fine, de la data comunicării răspunsului administrației sau, în lipsă, de la expirarea celor 30 de zile, particularul are 6 luni pentru introducerea acțiunii în justiție - cum prevede şi art. 11 alin. (1) din lege, termen calificat expres de legiuitor ca fiind unul de prescripție. Cele trei termene care circumscriu momentele contenciosului administrativ nu sunt însă adiționate matematic. Astfel, odată formulată plângerea prealabilă, automat primul termen de 30 de zile se întrerupe și începe să curgă următorul termen pentru răspunsul administrației. La fel, răspunsul administrației declanşează termenul de 6 luni pentru acțiunea în justiție. Aceeași succesiune temporală se aplică și în materia refuzului nejustificat de a soluționa o cerere. În ultima situație însă nu mai este necesară procedura administrativă prealabilă, ci doar o dovadă a refuzului.

\section{2}


recunoscută doar în termenul de 6 luni de la primirea răspunsului la cerere sau la expirarea acestui termen (3). Le vom aborda pe rând.

a) Formularea unei cereri către administrație. Lipsa unui termen general reglementat în acest sens. Există termene speciale?

a) Primul moment al procedurii este acela în care particularulreclamant formulează o cerere către administrație, în considerarea unei vocații73 căreia vrea să îi confere certitudine transformând-o în drept. Această petiție apare ca necesară, neputând fi conceput un refuz expres sau implicit în lipsa unei solicitări prealabile, aşa cum s-a subliniat și în jurisprudență:

„În mod evident, pentru a discuta despre existența unui refuz nejustificat este necesar ca în prealabil să se constate existența unei cereri formulate de partea vătămată și în raport de conținutul concret [al] acestei cereri urmează a se analiza în ce măsură refuzul autorității are caracter nejustificat în sensul dispozițiilor legale anterior citate ${ }^{74}$ ".

În legătură cu această cerere, regula este aceea că, în lipsa unui termen legal general, ea poate fi formulată oricând. Mai mult, având în vedere că prin aceasta particularul solicită un lucru pentru sine, se poate constata că cererea va fi formulată atunci când particularul consideră de cuviință sau, după caz, când se produce un fapt care creează premisele

73 În viziunea noastră, se poate pune semnul egalității între „vocație” și „interesul legitim privat”, aşa cum este acesta definit în art. 2 alin. (1) lit. p) din Legea nr. 554/2004 a contenciosului administrativ: „posibilitatea de a pretinde o anumită conduită, în considerarea realizării unui drept subiectiv viitor și previzibil, prefigurat”.

74 Curtea de Apel Târgu Mureș, Secția a II-a civilă, de contencios administrativ și fiscal, dec.: 471/o9 septembrie 2020, https://sintact.ro/\#/jurisprudence/534514792/1/decizie-nr-471-2020-din09-sept-2020-curtea-de-apel-targu-mures-obligatia-de-a-face-contencios..., consultat la 1 octombrie 2020.

\section{3}

SUBB Iurisprudentia nr. 1/2021 
transformării vocației sale într-un drept, și în acest fel se naște interesul demersului său procedural. Astfel, anterior momentului în care se formulează cererea şi în afara procedurii declanşate de această solicitare a particularului, există o perioadă în care el are doar o vocație, o îndreptățire de a pretinde pentru sine un drept viitor, prefigurat. Odată ce acest interes legitim privat se naşte - de regulă ca urmare a unei împrejurări exterioare și străine de voința sa - particularul este nevoit să iasă din pasivitate și să acționeze pentru a-și valorifica propria vocație.

b) Există însă texte speciale care prevăd condiționări temporale ale posibilității particularului de a formula o cerere către administrație. De pildă, potrivit art. 22 alin. (1) al Legii nr. 10/2001 privind regimul unor imobile preluate în mod abuziv în perioada 6 martie 1945-22 decembrie 1989, republicată 75 potrivit căruia „Persoana îndreptățită va notifica în termen de 6 luni de la data intrării în vigoare a prezentei legi [s.n., A-C.L.] persoana juridică deținătoare, solicitând restituirea în natură a imobilului”. În acest caz particular, vocația s-a născut ca urmare a intrării în vigoare a legii ce reglementează procedura de restituire (deci prin intervenția unei împrejurări exterioare), iar transformarea acesteia în dreptul de proprietate imobiliară este condiționată de formularea notificării în termenul prevăzut expres. În acest sens, făcând obiectul a numeroase excepții de neconstituționalitate ${ }^{76}$, prevederea amintită a suscitat totodată dezbateri

75 Publicată în M.of.: 75/14 februarie 2001, republicată în M.of.: 279/4 aprilie 2005, republicată în temeiul art. VII din titlul I al Legii nr. 247/2005 în M.of.: 798/2 septembrie 2005, în vigoare din 14 februarie 2001.

76 Într-o recentă decizie, sesizată fiind cu excepția de neconstituționalitate a dispozițiilor art. 22 alin. (1) și alin. (5) din Legea nr. 10/2001, Curtea Constituţională a României a statuat în sensul că „(...) prevederile de lege criticate în cauza de față au mai format, în repetate rânduri, 
raportat la natura termenului în care notificarea trebuie formulată. Astfel, sa remarcat faptul că termenul prevăzut de lege pentru notificarea persoanei deținătoare nu ar fi un termen procedural, ci, dimpotrivă, unul de drept substanțial, a cărui nerespectare atrage pierderea dreptului de a solicita (și obține) în justiție măsuri reparatorii, în natură sau prin echivalent777. Alte astfel de termene ce impun acţiunea particularului în sesizarea administrației pot fi regăsite în Legea nr. 18/1991 privind fondul funciar,

obiect al controlului de constituționalitate, instanța de contencios constituțional pronunțânduse prin mai multe decizii în sensul respingerii, ca neîntemeiată, a excepției de neconstituționalitate. În acest sens sunt, de exemplu, deciziile nr. 344 din 18 septembrie 2003, publicată în Monitorul Oficial al României, Partea I, nr. 776 din 5 noiembrie 2003, nr. 185 din 27 aprilie 2004, publicată în Monitorul Oficial al României, Partea I, nr. 490 din 1 iunie 2004 (...). În jurisprudența menționată, Curtea a reținut că, prin art. 22 și următoarele din Legea nr. 10/2001, a fost instituită o procedură administrativă ce are ca scop restituirea în natură a imobilelor - terenuri sau construcții - de către persoana juridică deținătoare, prin decizie sau dispoziție motivată a organelor sale de conducere. Legiuitorul a circumscris exercitarea dreptului la restituire a imobilelor de respectarea unor termene, aşa cum este și termenul prevăzut de art. 22 alin. (5) din Legea nr. 10/2001, în interiorul căruia trebuie trimisă notificarea către persoana juridică deținătoare a imobilului. Curtea a statuat că acest termen nu este de natură să aducă atingere dreptului de proprietate privată, având în vedere faptul că recunoașterea sine die a posibilității persoanei interesate de a declanșa procedura de recuperare a imobilelor preluate abuziv de către stat ar fi fost de natură să genereze un climat de insecuritate juridică în domeniul proprietății imobiliare. Mai mult, potrivit dispozițiilor art. 44 alin. (1) teza a doua din Constituție, exercitarea dreptului de proprietate trebuie să se facă în limitele legii, iar legiuitorul ordinar este competent să fixeze cadrul juridic pentru exercitarea acestuia, instituind limitări rezonabile în valorificarea ca drept subiectiv garantat, în așa fel încât să nu vină în coliziune cu interesele generale sau cu interesele particulare legitime ale altor subiecte de drept"; a se vedea Decizia nr. 226/2019 referitoare la respingerea excepției de neconstituţionalitate a prevederilor art. 22 alin. (1) și (5) din Legea nr. 10/2001 privind regimul juridic al unor imobile preluate în mod abuziv în perioada 6 martie 1945-22 decembrie 1989, publicată în M.of.: 550/4 iulie 2019.

77 M. NiCOLAE, Proceduri de restituiri, în Regimul juridic al imobilelor preluate în mod abuziv. Legea $n r$. 10/2001 comentată și adnotată, vol. I, în F.A. BAIAS, B. DUMITRACHE, M. NicOlAE, ed. a II-a, Ed. Rosetti, București, 2002, nr. 155, p. 207. În acest context, „dreptul de a solicita măsuri reparatorii” echivalează cu o vocație, iar pierderea acestuia semnifică pierderea respectivei vocații.

\section{5}


republicată $7^{8}$. În acest sens, art. 9 alin. (3)79, art. 37 alin. (2) ${ }^{80}$ prevăd expres termene în care particularul trebuie să formuleze cererea de reconstituire a dreptului de proprietate.

Un alt termen special pentru sesizarea administrației ar putea fi cel în care particularul trebuie să formuleze cererea de anulare a obligațiilor fiscale accesorii, prevăzut în Ordinul nr. 2100/2020 al ministrului finanțelor publice pentru aprobarea Procedurii de anulare a obligațiilor de plată accesorii ${ }^{81}$. În acest sens, ordinul prevede că cererea pentru anularea obligațiilor de plată accesorii trebuie depusă cel mai târziu la data de 15 decembrie 2020. Şi în această ipoteză interesul legitim privat, dreptul viitor prefigurat se naște ca urmare a noului context legislativ - aspect exterior voinței particularului.

În concluzie, există aşadar unele termene speciale în domenii variate, nu și unul general, în materia contenciosului administrativ, care să restrângă temporal dreptul particularului de a sesiza administrația. În mod evident, în

78 Publicată în M. of.: 37/20 februarie 1991, republicată în M.of.: 1/5 ianuarie 1998, în vigoare din 20 februarie 1991.

79 Art. 9 alin. (3) din Legea nr. 18/1991 prevede, raportat la reconstituirea dreptului de proprietate asupra terenurilor arabile faptul că „Cererea se depune la primăria localităţii sau, după caz, al primăriile localităţilor în a căror rază teritorială se află terenul pentru care urmează să fie reconstituit dreptul de proprietate, personal sau prin poștă, cu confirmare de primire, până la data de 31 decembrie 1998 [s.n., A-C.L.], sub sancțiunea decăderii din termen”. 8oPotrivit art. 37 din Legea nr. 18/1991, „(1) Persoanele ale căror terenuri agricole au fost trecute în proprietate de stat, ca efect al unor legi speciale, altele decât cele de expropriere, și care se află în administrarea unităților agricole de stat devin, la cerere, acționari la societățile comerciale înființate, în baza Legii nr. 15/1990, din actualele unități agricole de stat. De aceleași prevederi beneficiază şi moștenitorii acestor persoane. (2) Cererea se depune, în termen de 30 de zile de la intrarea în vigoare a prezentei legi [s.n., A-C.L.] la primăria în a cărei rază teritorială este situat terenul".

${ }^{81}$ Acest ordin, publicat în 20 iulie 2020 a fost emis în contextul măsurilor fiscale adoptate de autorităţi în luna mai prin OUG 69/2020, menite să ajute contribuabilii să depăşească mai uşor problemele generate de COVID-19. 
lipsa unui factor declanşator, particularul va formula o cerere în momentul când va avea un interes concret, tinzând spre valorificarea unei vocații și transformarea acesteia în drept.

Lipsa unui termen general pentru formularea cererii în materia contenciosului administrativ ne permite să ajungem la concluzia că un ipotetic termen special în care se naște și există vocația particularului n-ar trebui să afecteze logica termenelor prevăzute de Legea nr. 554/2004. Regulile instituite prin legea amintită se declanșează numai după formularea cererii, astfel că reglementarea unui interval de timp pentru acest act nu intră în conflict şi nu poate modifica termenele din contenciosul administrativ, pentru că, prin ipoteză, nu există un termen general care să fie susceptibil de modificare.

\section{b) Răspunsul administrației publice. Termenul prohibitiv de 30 de zile}

În urma formulării cererii, administrația are la dispoziție un termen de 30 de zile în care să răspundă reclamantului - prin soluționarea pozitivă sau negativă a cererii acestuia.

Ca natură juridică, acesta nu poate fi caracterizat ca fiind termen de prescripție sau de decădere, având în vedere faptul că el nu este un termen în care particularul trebuie să se manifeste activ. Din contră, fiind o perioadă „de așteptare" pentru acesta, cele 30 de zile constituie un termen prohibitiv, caracterizat prin obligația de abținere de la orice act de procedură.

În doctrină s-a arătat și faptul că, din perspectiva administrației, acesta este un „termen procesual imperativ”, a cărui nerespectare poate 
atrage aplicarea de sancțiuni disciplinare celui care se face vinovat de nerezolvarea reclamației administrative în acest interval legal de timp ${ }^{82}$.

\section{c) Acțiunea în justiție. Termenul de prescripție de 6 luni. Posibilitatea reiterării cererii inițiale}

Potrivit art. 11 alin. (5) teza I din Legea nr. 554/2004 a contenciosului administrativ, termenul de 6 luni în care particularul este îndreptăţit să introducă acțiunea în contencios administrativ având ca obiect cenzurarea refuzului nejustificat este calificat expres ca termen de prescripție ${ }^{83}$. Doctrina a statuat că prin această modalitate de calificare a naturii juridice a celor 6 luni s-a realizat o corelare perfectă a reglementării speciale cu cea generală (Noul Cod civil) - aşa cum în materie civilă, termenul general de prescripție este cel de 3 ani, în materia contenciosului administrativ suntem în prezența unui termen special, mai scurt, de 6 luni, „expresie a privilegiului de jurisdicție de care se bucură administrația ${ }^{84}$.

Remarcăm și faptul că în doctrină a fost generalizată definiția instituției prescripției în ceea ce privește acțiunea în contencios administrativ, ca fiind ,acel mod de înlăturare a obligației unei autorităţi publice de a revoca un act administrativ, a soluționa o cerere sau a acorda despăgubiri unui

\footnotetext{
82 M. NiCOLAE, Tratat de prescripție extinctivă..., op.cit., p. 1027.

83 Această natură juridică stabilită legal a fost confirmată și în doctrină; a se vedea A. IoRGOVAN, Tratat de drept administrativ, ed. a 4-a, rev., Ed. ALL Beck, București, 2005, p. 1027.

84 Ov. Podaru, Despre prescripție ..., op.cit., p. 38. Autorul arată că, în esență „nu este vorba despre ideea că, într-un litigiu purtat cu administrația particularul nu ar fi egal cu aceasta, ci de faptul că un particular care se judecă cu administrația este într-o situaţie mai grea decât unul care a chemat în judecată un alt particular (...)”.
}

\section{8}


particular, prin stingerea dreptului material la acțiune al acestuia din urmă ca urmare a neexercitării sale în termenul stabilit de lege $\mathrm{e}^{85}$ ".

În contextul tratării problematicii termenului de introducere a acțiunii, un aspect de subliniat este distincția între durata de existență a dreptului subiectiv pretins şi termenele procedurale instituite de lege pentru satisfacerea acestui drept. Acest aspect a constituit obiect al disputelor doctrinare de-a lungul timpului, concluzia la care ne raliem fiind aceea că pierderea anumitor termene procedurale nu poate conduce prin sine la o pierdere a dreptului ce trebuie valorificat prin procedurile stabilite de lege. În acest sens, în cazul în care, prin ipoteză, particularul a pierdut termenele pentru a ataca refuzul nejustificat al administrației, în realitate toate aceste termene procedurale curg generate fiind de prima sa cerere, neafectând însă dreptul subiectiv în esența sa. În măsura în care această primă cerere este respinsă (sau pur și simplu ignorată), având în vedere că dreptul său nu a fost afectat, dacă pentru viitor acesta hotărăşte să formuleze o nouă cerere, atunci vor curge alte termene, generate de cererea respectivă. Pierderea termenelor în cazul tăcerii administrației nu poate avea ca efect pierderea dreptului subiectiv însuşi - dacă este imprescriptibil - ci doar a dreptului procedural de a i se răspunde la prima cerere ${ }^{86}$. Expirarea

\footnotetext{
85 M. Nicolae, Tratat de prescripție extinctivă ..., op.cit., p.1148.

86 Încă din perioada interbelică, a fost subliniată ideea potrivit căreia , Faptul de a nu fi făcut recursul în termen, nu constituie pentru particular o decădere de a mai face o altă cerere; el a pierdut numai dreptul de a face recurs față de prima cerere, pe care a omis să o atace cu recurs în termen.”, a se vedea: P. Negulescu, Tratat de drept administrativ, ed. a IV-a, Ed. Institutul de arte grafice E. MARVAN, București, 1934, p. 374. Mai mult, în ipoteza atitudinii pasive a administrației care a condus la pierderea termenului, acelaşi autor subliniază: „Colectivitatea nu are interes ca particularul să fie vexat, nesocotit, împiedecat în activitatea sa de funcţionarii puşi tocmai ca să ajute pe individ, să-i sprijine activitatea, căci progresul individual constituie
}

\section{9}


termenului - ca urmare a pasivității administrației (cum este cazul în speța de față) „trebuie interpretată cât mai mult în favoarea particularilor, iar nu în defavoarea lor ${ }^{87}$.

Analizând cele trei momente temporale în ipoteza refuzului nejustificat de a soluționa o cerere, devine vizibilă logica lor. Astfel, îndeplinirea actului asociat primului moment temporal determină întreruperea ${ }^{88}$ termenului iniţial şi curgerea termenului de 30 de zile pentru răspunsul administrației. Formularea (şi comunicarea) acestuia declanşează automat curgerea termenului de 6 luni pentru introducerea acțiunii în contencios administrativ. Astfel, efectuarea unui act provoacă imediat

progresul colectivităței; ea nu poate să aibă interes ca un cetățean să fie decăzut din drepturile sale publice [...]".

${ }^{87 C . G . ~ R A R I N C E S C U, ~ C o n t e n c i o s u l ~ a d m i n i s t r a t i v ~ r o m a ̂ n, ~ e d . ~ a ~ 2-a, ~ a n a s t a t i c a ̆, ~ E d . ~ U n i v e r s u l ~}$ Juridic, București, 2019, p. 283. Ideea expusă este tratată și de alți autori, ce și-au exprimat convingerea în sensul existenței posibilității de reiterare a cererii de către particular, în sensul că „este absolut ilogic ca această atitudine a administrației, care nu presupune nici o schimbare vizibilă a situației raportat la ceea ce exista înainte de sesizarea acesteia, să se transforme întro clipă într-o situație iremediabilă și absolut catastrofală pentru particular (...) Cu alte cuvinte, am spune noi, tăcerea poate încălca un drept, dar nu poate determina stingerea acestuia. De aceea i s-a recunoscut - sau ar fi trebuit să i se recunoască - dreptul său absolut firesc la reiterarea cererii, ca un corolar al principiului - să-i spunem așa - al «imprescriptibilității stării de legalitate»", a se vedea Ov. PoDARu, Paradoxurile tăcerii: de la non-voință la act. Studiu de drept administrativ, în Studia Universitatis Babeș-Bolyai Iurisprudentia, nr. 1/2003, p. 103. Totodată, s-a susținut că „cel care se consideră vătămat într-un drept recunoscut de lege sau într-un interes legitim, după caz, prin refuzul unei autorități publice de a răspunde petiționarului în termen de 30 de zile de la înregistrarea cererii respective (...) poate, chiar după prescripția dreptului la acțiune contra refuzului nejustificat de rezolvare a acestei cereri, să reitereze (formuleze din nou) cererea, cât timp dreptul său material mai este în ființă (...)”, a se vedea M. NicolaE, Tratat de prescripție extinctivă ..., op.cit., p. 991.

88 În acest context, folosim noțiunea de „întrerupere” tocmai pentru a sublinia succesiunea termenelor din contenciosul administrativ. Astfel, odată cu efectuarea actului asociat unuia dintre cele trei momente temporale începe să curgă termenul următor, nemaiprezentând relevanță pentru cei implicați perioada de timp rămasă (în măsura în care actul s-a realizat în interiorul termenului inițial, care nu s-a scurs în integralitate). 
curgerea termenului pentru următorul act, indiferent de natura substanțială sau procedurală a termenelor în discuție.

2. Termenul de 90 de zile instituit prin Regulamentul CSM și natura sa juridică dificil de găsit

În ceea ce privește cariera magistraților, Regulamentul adoptat prin Hotărârea Plenului Consiliului Superior al Magistraturii nr. 621/2006, prevede un termen de 90 de zile, în care persoana care a obținut un anumit punctaj şi îndeplinește criterii specifice poate să formuleze o cerere pentru a valorifica rezultatul obținut. Mecanismul concret este acela că, prin validarea concursului, candidatul inițial nepromovat dobândește concomitent vocația de a promova în funcţie în măsura în care își manifestă voința în acest sens (prin formularea unei cereri) și, cel mai important, în măsura în care devine vacant un loc în cadrul instituției pentru care a optat.

\section{a) Termen de drept material sau termen de procedură?}

Pentru început, pentru a da termenului de 90 de zile o natură juridică, trebuie să stabilim dacă acesta privește exercitarea unui drept substanțial sau, din contră, a unui drept procedural. Neexistând un cadru procesual şi nefiind în prezența unui act de procedură care să trebuiască să fie îndeplinit, este clar că nu poate fi vorba de un termen pentru exercitarea unui drept procedural.

În consecință, termenul de 90 de zile privește un drept substanțial. Mai mult, dreptul la valorificarea rezultatului concursului este, ca natură juridică, unul potestativ, petentul urmărind prin manifestarea sa de voință constituirea unei noi situații juridice. Totuşi, spre deosebire de situaţia potestativității „pure şi simple”, în cazul de față, pe lângă simpla exprimare a opțiunii, este necesară îndeplinirea unei condiții exterioare, și anume 
vacantarea unui loc în cadrul instituției pentru care petentul a optat. Limitând în timp existența unei vocații, termenul de 90 de zile nu poate fi decât un termen de drept material, fără a constitui însă un termen de prescripție. Pe de o parte, nu se poate admite că în interiorul acestui termen se naşte și dreptul la acțiune în justiție pentru protejarea vocației în cauză ${ }^{89}$. Pe de altă parte, nu se poate spune că la expirarea termenului de 90 de zile subzistă un drept „imperfect ”ce poate fi invocat pe cale de excepție și o obligație naturală corelativă.

Cele 90 de zile desemnează intervalul în care se naște vocația magistratului, dreptul lui viitor prefigurat şi totodată, perioada în care acest drept viitor se poate transforma în certitudine printr-o manifestare de voință explicită. Totuși, manifestarea propriei voințe nu este suficientă prin sine, căci valorificarea interesului legitim privat depinde și de o împrejurare exterioară - existența unui loc vacant. Vorbim astfel de o vocație sub condiție

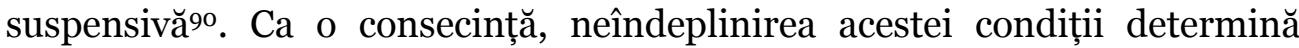

89 Așa cum foarte clar prevedea art. 1886 al C.civ. 1864: „Nicio prescripție nu poate începe a curge mai înainte de a se naște acțiunea supusă acestui mod de stingere”. Totodată, potrivit art. 2523 al C.civ. 2009: „Prescripția începe să curgă de la data când titularul dreptului la acțiune a cunoscut sau, după împrejurări, trebuia să cunoască nașterea lui”.

90 Mai corect este să afirmăm că actul care dă efect promovării în situația candidaților inițial respinși este afectat de condiția suspensivă a vacantării unui loc în cadrul instanței sau parchetului vizat în intervalul de timp prevăzut prin regulament al CSM. Cu privire la modalitățile actului administrativ, doctrina s-a pronunțat în sensul că în această materie termenul și condiția sunt identice - ca instituție juridică - cu cele din dreptul civil, însă au în dreptul administrativ o arie diferită de aplicabilitate; a se vedea Ov. Podaru, Drept administrativ... op.cit., p. 49. În dreptul administrativ, deși identice ca mod de funcționare, se poate observa că instituirea modalităților nu este rezultatul voinței concordante a părților, ci se realizează prin acte administrative normative (cum este și în cazul speței de față, în care condiția suspensivă a existenței unui loc vacant este instituită prin Regulament al CSM). Translatarea instituției juridice a modalităților în dreptul administrativ este însă permisă de art. 28 alin. (1) din Legea contenciosului administrativ, potrivit căruia „Dispozițiile prezentei 
caducitatea acestei vocații. Practic, în lipsa solicitării de valorificare și a locului vacant, la expirarea celor 90 de zile, interesul legitim privat se stinge. Astfel, concluzia la care ajungem este că cele 90 de zile desemnează un termen de decădere substanțial, la expirarea acestei perioade stingânduse chiar vocația la valorificare ${ }^{91}$.

legi se completează cu prevederile Codului civil și cu cele ale Codului de procedură civilă, în măsura în care nu sunt incompatibile cu specificul raporturilor de putere dintre autoritățile publice, pe de o parte, şi persoanele vătămate în drepturile sau interesele lor legitime, pe de altă parte”. În ceea ce privește actele unilaterale, potrivit art. 1325 Cod civil, „Dacă prin lege nu se prevede altfel, dispozițiile legale privitoare la contracte se aplică în mod corespunzător actelor unilaterale" . Modalităţile instituite de regulă pe cale convenţională sunt aplicabile astfel şi actelor unilaterale de drept civil, putând fi translatate şi în materia actului juridic administrativ - ca regulă unilateral, atât timp cât nu există o incompatibilitate cu specificul raporturilor de drept public. Aplicabilitatea modalităţilor în dreptul administrativ nu poate fi exclusă nici din perspectiva faptului că dreptului sau vocației având ca izvor actul administrativ normativ, în speță art. 30 din Regulamentul CSM, îi corespunde o obligație corelativă a autorității - de a da efect cererii de valorificare a rezultatelor concursului - la rândul ei sub condiția suspensivă a existenței unui loc vacant.

91 Pentru a ajunge la această concluzie, trebuie să raportăm termenul de 90 de zile la celelalte posibile clasificări expuse în prezentul studiu. Remarcăm astfel că acesta se aseamănă într-o măsură însemnată cu termenul extinctiv și termenul prefix. Perechea „termen extinctiv - termen suspensiv" este întâlnită în materia modalităților actelor juridice civile, și nu în ceea ce privește efectele acestor acte (printre care se numără și drepturile subiective). Însă, în măsura în care un act este afectat de un termen extinctiv, este posibil ca dreptul ce constituie unul dintre efectele actului respectiv să fie afectat de un termen de decădere substanțială. Astfel, este foarte posibil ca termenul extinctiv și cel de decădere substanțială să desemneze acelaşi lucru, doar că cel din urmă vizează dreptul - ca efect al actului juridic. Și noțiunea de termen prefix este extrem de apropiat de cel de decădere substanțială. În acest sens, tratând problematica termenelor de garanție pentru conformitate, în doctrină acestea au fost clasificate ca termene prefixe, adăugându-se și faptul că se aseamănă cu termenele de decădere, cu care uneori se identifică; a se vedea I. F. POPA, Regimul juridic al termenelor în materia garanției pentru conformitate, în Revista Română de Drept Privat, nr. 4/2007, https://sintact.ro/\#/publication/151006925, consultat la data de 12.11.2020. Distincția dintre termenele de decădere substanțială și termenele prefixe ar putea consta în aceea că primele pot să fie în anumite situații de forță majoră susceptibile de întrerupere. Dacă am admite acest lucru, trebuie să ne întrebăm dacă nu cumva astfel de termene (cum este și cel din speța de față) nu ar fi fost suspendate prin Decretul nr. 195 din 16 martie 2020 privind instituirea stării

\section{3}

SUBB Iurisprudentia nr. 1/2021 


\section{b) Termen peremptoriu sau dilatoriu?}

În considerarea celor expuse mai sus, este evident că cele 90 de zile nu pot reprezenta un interval de timp în care petentului să-i fie interzisă orice conduită activă, respectiv să-i fie impusă pasivitatea. Din contră, în această perioadă este necesar să-și manifeste voința în sensul formulării cererii de valorificare, tocmai pentru ca vocația de promovare să se transforme în drept subiectiv. Așa cum am arătat însă, acțiunea sa este necesară, dar nu și suficientă. Căci jocul condiției suspensive (vacantarea unui loc) este de natură să determine eficacitatea ori, după caz, caducitatea vocației sale.

În concluzie, în considerarea acestei atitudini active, în mod cert termenul instituit prin Regulamentul CSM este unul imperativ (peremptoriu) din perspectiva candidatului. Din perspectiva CSM însă, în intervalul de timp de 90 de zile nu există o obligație de a acționa; dimpotrivă, acestui organ administrativ nu îi rămâne decât să adopte o conduită pasivă.

Soluția pe care o propunem. Critica raționamentului instanței supreme

Așa cum am arătat, există termene care afectează chiar existența drepturilor subiective şi termene a căror îndeplinire atrage doar ineficacitatea acestor drepturi. Totodată, există, pe de o parte, termene în care se impune

de urgență pe teritoriul României emis de Președintele României, (M.of.: 212/16 martie 2020), care stabilește la art. 41 că „Prescripțiile și termenele de decădere de orice fel nu încep să curgă, iar, dacă au început să curgă, se suspendă pe toată durata stării de urgență instituite potrivit prezentului decret, dispozițiile art. 2.532 pct. 9 teza a II-a din Legea nr. 287/2009 privind Codul civil sau alte dispoziții legale contrare nefiind aplicabile”. privind Codul civil sau alte dispoziții legale contrare nefiind aplicabile”. Distinct de termenul de decădere substanțial, termenul prefix (cum este cel în materia garanției pentru conformitate) curge chiar în măsura luării unor măsuri excepționale determinate de cazuri de forță majoră, tocmai datorită caracterului obiectiv al acestuia. În consecință, credem că această posibilitate de suspendare/întrerupere este cea care diferențiază cele două termene, regimul lor juridic fiind aproape identic.

\section{4}

SUBB Iurisprudentia nr. 1/2021 
îndeplinirea unor acte procedurale și termene în care este oprită efectuarea oricărui act, pe de altă parte. Având în memorie clasificările expuse anterior, trebuie să analizăm, mai întâi, care este raportul între cele 90 de zile și logica termenelor din contenciosul administrativ iar, mai apoi, care este modul în care Înalta Curte a tranșat această problemă.

(1) Corelarea termenului de 90 de zile cu termenele reglementate de Legea nr. 554/2004 a contenciosului administrativ.

În privința acestor termene, aşa cum am arătat, succesiunea lor în timp presupune că efectuarea actului corespunzător în termenul inițial (termen special) declanșează automat curgerea următoarelor intervale de timp. Nu există astfel o adiționare pur matematică a acestor termene, ele declanşându-se începând cu primul termen până la cel din urmă la momentul efectuării actului procedural.

Astfel, se pot pune în discuție cel puțin două interpretări referitoare la termenul special prevăzut de Regulamentul CSM - fie aceea că cele 90 de zile reprezintă intervalul în care persoana îndreptățită își manifestă vocaţia printr-o cerere de valorificare, iar odată manifestată voința sa, termenul de 90 de zile este întrerupt și este declanșată automat curgerea termenului de 30 de zile pentru răspunsul administrației; fie interpretarea potrivit căreia termenul de 90 de zile vizează atât formularea cererii cât și intervalul în care trebuie să răspundă administrația, interpretare la care s-a oprit și Înalta Curte de Casație și Justiție şi pe care o vom trata ulterior.

În opinia noastră, singura interpretare corectă este cea potrivit căreia acest termen marchează chiar perioada de existență a vocației particularului de a valorifica rezultatele obținute în urma concursului, orice perioadă în afara intervalului de 90 de zile echivalând cu inexistența vocaţiei în cauză. În 
acest sens, trebuie făcută distincția între termenul în care există posibilitatea de valorificare a unei vocații a particularului și termenele care compun procedura efectivă de valorificare a acesteia. Există un termen în care particularul își manifestă voința pentru a evita stingerea vocației sale înțeleasă ca interes legitim privat, pe de o parte, și, pe de alta, diferite termene aplicabile tocmai ca urmare a manifestării sale de voință. În mod firesc, aplicând aceeași logică a termenelor din contenciosul administrativ, formularea cererii în termenul de 90 de zile va determina automat întreruperea aceluiași termen și curgerea termenului de 30 de zile pentru soluționarea cererii în cauză. Chiar în lipsa unui răspuns la cererea sa, nu există riscul stingerii definitive a vocației sale. Mai mult, în absența unui răspuns, de la momentul expirării termenului de 30 de zile curge termenul de 6 luni pentru exercitarea acțiunii în justiție, iar acțiunea sa nu poate fi respinsă ca lipsită de interes sau ca prematură, tocmai pentru că, dacă cele două condiții sunt îndeplinite (exercitarea opțiunii și locul vacant), vocația sa devine drept subiectiv și poate fi apărată în contenciosul administrativ.

\section{Unde a greșit instanța supremă în interpretarea sa?}

Pentru a lămuri problemele generate de ambiguitatea instanței supreme în soluționarea speței de față, să reiterăm cele două părți ale raţionamentului acesteia:

(i) pe de o parte aceasta arată că „dispozițiile art. 2 alin. (1) lit. h) din Legea nr. 554/2004 modificată și completată nu sunt aplicabile în cauză. Legea contenciosului administrativ reprezintă legea generală în materia contenciosului administrativ, iar termenul de 30 de zile se aplică în domeniile în care, prin legi speciale nu se prevede un alt termen” respectiv că „(...) termenul de 30 de zile din Legea nr. 554/2004 modificată și completată nu se aplică în cadrul

\section{6}


procedurii valorificării rezultatelor concursului de promovare. În cauză se aplică numai termenul de 3 luni prevăzut de art. 30 alin. (1) din Regulament";

(ii) pe de altă parte însă se argumentează că „la împlinirea acestui termen intimatul are obligația să soluționeze cererea contestatoarei prin care a cerut valorificarea rezultatelor concursului de promovare (...)"

Așadar, în prima parte a raționamentului său, instanța supremă susţine ideea înlocuirii termenului de 30 de zile prevăzut în materia contenciosului administrativ cu cel de 90 de zile. Prin înlocuire s-ar înțelege astfel o preluare a scopului și funcțiilor pentru care a fost instituit termenul de 30 de zile - ca perioadă de timp pe care administrația o are la dispoziție pentru a răspunde cererii particularului. Raționamentul inițial este însă curmat brusc, prin ultima teză din considerentele curții, potrivit căreia soluționarea cererilor de valorificare are loc doar după expirarea termenului de 90 de zile.

Contradicția în argumentare este evidentă - pe de o parte se afirmă că termenul de 90 de zile înlocuiește termenul de 30 de zile (însemnând că tot acest interval este pus la dispoziția CSM pentru a răspunde cererilor de valorificare), iar pe de alta, se afirmă că soluționarea are loc doar la expirarea celor 90 de zile deci, printr-o logică firească, acest termen special nu înlocuiește scopul și rolul termenului prevăzut în Legea nr. 554/2004 a contenciosului administrativ. Așadar, termenul de 90 de zile se substituie sau succedă celui de 30 de zile? În continuare vom arăta însă că niciuna dintre aceste „jumătăți de raționament” (care oricum nu se potrivesc una cu cealaltă) nu poate fi acceptată nici dacă le-am privi, pe fiecare, în mod independent. 
(1) Soluția înlocuirii termenului prevăzut în legea organică nu este corectă

Mai întâi, Înalta Curte de Casație şi Justiție statuează că termenul de 90 de zile, prin natura sa specială, ar deroga de la Legea nr. 554/2004 a contenciosului administrativ și ar înlătura de la aplicabilitate termenul de 30 de zile instituit prin art. 2 alin. (1) lit h) din această lege. Sunt însă suficiente argumente care se opun acestei idei:

1. Pentru început, considerăm că, existând o reglementare generală, cu forță juridică superioară - Legea nr. 554/2004 - care prevede expres un termen procedural în care administrația trebuie să răspundă solicitării particularului, şi ținând cont și de faptul că reglementarea inferioară regulamentul adoptat de Plenul CSM - nu conține o prevedere în sensul că acest termen ar desemna perioada în care administrația răspunde cererii particularului, rezultă că, în privința acestui răspuns rămâne să se aplice, în absența unei norme speciale, textul comun din Legea nr. 554/2004 a contenciosului administrativ.

2. Chiar în măsura în care s-ar recunoaște posibilitatea de înlocuire a termenului general, termenul special prevăzut de un act administrativ cu forță juridică inferioară nu poate să îl depășească ca durată, întrucât instituie o limitare, o condiționare (în ceea ce-l privește pe particularul obligat la o atitudine pasivă în termenul mai îndelungat). Așa cum am arătat în prezentul studiu, un act administrativ normativ mai puțin favorabil decât legea în executarea căruia a fost adoptat nu trebuie să fie aplicat într-o situație concretă, în detrimentul legii.

3. Totodată, termenul de 30 de zile pus la dispoziția administrației pentru a răspunde cererii particularului nu poate primi prin interpretare aceeași natură juridică cu termenul de 90 de zile, ca să putem afirma că se pot 
exclude reciproc de la aplicare. Privit din perspectiva particularului, termenul de 30 de zile prevăzut de Legea nr. 554/2004 a contenciosului administrativ nu poate fi cuprins în categoria termene de prescripție - termene de decădere, fiind un termen prohibitiv (iar nu unul imperativ, ca și cel de 90 de zile), în care particularul trebuie să se abțină de la efectuarea oricărui act procedural, în așteptarea răspunsului organului administrativ sesizat. Astfel, el nu are nici o înrâurire asupra vocației particularului. În măsura în care am aplica în situația concretă raționamentul instanței supreme, am ajunge practic să dăm unui singur termen două semnificații și două naturi juridice diferite - pe de o parte, s-ar impune particularului să acționeze pentru valorificarea vocației sale prin formularea cererii, pe de altă parte, acesta ar fi obligat să adopte o conduită pasivă, în așteptarea unui răspuns dat la un moment în care în mod cert nu mai există un loc vacant și, ca o consecință, vocația sa e stinsă. Or, nu putem concepe un termen care să fie, pentru aceeași parte a unui raport juridic concret, simultan imperativ - obligând la o conduită anume prescrisă - şi prohibitiv - interzicând orice formă de acțiune. Nonsensul situației este evident.

4. Mai mult, dacă ar fi să considerăm termenul de 90 de zile ca reprezentând atât intervalul pentru răspunsul administrației, cât și pentru valorificarea interesului legitim privat, s-ar putea ajunge la o concluzie contrară logicii, dar și ideii de echitate: la trecerea acestuia, în ipoteza lipsei unui răspuns din partea administrației, particularul ar putea fi privat în fapt de orice posibilitate de acţiune, o contestație având ca obiect refuzul 
nejustificat al administrației fiind lipsită de interes, pentru că oricum vocația acestuia de a-și valorifica rezultatul obținut s-a stins ${ }^{92}$.

5. În fine, pornind de la aceeași idee, a dublei naturi juridice a acestui termen, am putea ajunge la o altă concluzie absurdă: presupunând că în acest caz particularul ar formula cererea în penultima zi din intervalul de 90 de zile, administrația ar avea la dispoziție o singură zi pentru a primi și soluționa petiția, lucru în primul rând imposibil și apoi în mod sigur în defavoarea particularului, căci acesta nu are cum să-și dea seama că imediat începe să curgă împotriva sa termenul pentru introducerea contestației. Așadar, această modalitate de interpretare trebuie exclusă.

(2) Nici soluția nașterii obligației CSM la soluționarea cererii doar după trecerea celor 90 de zile nu este corectă

În continuarea raționamentului său, Înalta Curte afirmă că doar la împlinirea termenului de 90 de zile CSM ar avea obligația să soluționeze cererea contestatoarei prin care a cerut valorificarea rezultatelor concursului. Altfel spus, formularea cererii nu ar întrerupe termenul de 90 de zile care ar curge în continuare, CSM având obligația de a răspunde doar după scurgerea acestui termen. Și acestei idei i se pot aduce următoarele critici:

1. Prima problemă pe care o ridică această interpretare este legată de corelarea termenului de 90 de zile cu logica termenelor din contenciosul administrativ. Practic, instanța supremă șterge cu buretele raționamentul

\footnotetext{
92 Astfel, dacă termenul de 90 de zile ar constitui în acelaşi timp și termenul de răspuns și termenul în limitele căruia există chiar vocația (interesul legitim privat la promovarea prin valorificarea rezultatelor concursului), am putea ajunge în situația absurd în care, la expirarea termenului și în lipsa unui răspuns, particularul îndreptățit la formularea unei acţiuni în contencios administrativ, să nu mai aibă o vocație de protejat pe calea acestei acțiuni.
} 
potrivit căruia termenul de 30 de zile este înlocuit, nejustificând în vreun fel dispariția acestuia din succesiunea cronologică firească. Or, în măsura în care se înlătură de la aplicare un termen instituit prin lege organică, instanța trebuie să arate în concret cauza dispariției sale. Mai mult, dacă ar fi să considerăm că nu se mai aplică termenul de 30 de zile, instanța supremă lasă neclarificată a altă dilemă: aceea de a ști dacă există o un interval de timp determinat în care organul administrativ sesizat are obligația de a răspunde cererii petentului sau acesta poate să soluționeze cererea sine die.

2. Totodată, această a doua interpretare ar putea determina stingerea vocației doar prin trecerea timpului. Practic, după formularea cererii, magistratul este obligat să se abțină să acționeze în tot intervalul de timp cât subzistă vocația sa. Iar după trecerea acestui interval, chiar în măsura în care ar dori să acționeze, nu ar mai putea, vocația sa fiind stinsăa3. Aplicarea acestui raționament nu numai că reprezintă un nonsens, dar, mai mult, poate

$93 \mathrm{Cu}$ referire la instituirea unor termene care conduc practic la o golire de conținut a vocațiilor recunoscute particularilor, s-a pronunțat și Curtea Europeană a Drepturilor Omului, prin hotărârea pronunțată de secția II în data de 24 februarie 2004 în cauza Vodarenska Akciova Spolecnost. În cauza adusă în fața Curții, reclamanta a fost parte a unei proceduri care s-a finalizat în apel cu o decizie defavorabilă. De aceea, aceasta a introdus un recurs în fața instanței supreme și, în același timp, un recurs în fața Curții Constituționale. Al doilea recurs a fost respins de către instanța constituțională ca fiind inadmisibil, pe motiv că reclamanta trebuia să epuizeze anterior celelalte mijloace de recurs, anume recursul în fața instanței supreme, care era încă pendinte. După ce recursul său la instanța supremă a fost respins ca inadmisibil, reclamanta a introdus din nou recursul în fața Curții Constituționale. Aceasta a considerat că recursul este tardiv, întrucât termenul de sesizare se calculează de la data deciziei în apel, cât timp recursul său la instanța supremă a fost inadmisibil. În acest context, Curtea Europeană a Drepturilor Omului, raportându-se la art. 6 din Convenție a statuat că instituirea unor termene pentru sesizarea instanțelor este o limitare implicită a accesului la justiție, justificată de principiul securității raporturilor juridice. Totuși, aceste termene nu trebuie interpretate astfel încât să anuleze substanța dreptului de acces la justiție. Or, modul în care Curtea Constituțională a interpretat regulile privind termenele în speța de față a condus exact la un astfel de rezultat. 
crea premisele unui exces de putere în raporturile dintre particular şi administrație, cea din urmă putând transforma tăcerea într-o armă de anihilare a oricăror pretenții subsecvente ale acestuia. Pasivitatea administrației ar constitui un „privilegiu” acordat acesteia, exercitat tocmai cu scopul ca scurgerea termenului și absența unui răspuns să conducă la o stingere iremediabilă a interesului legitim al particularului, care ar fi îndeplinit condițiile legale în vederea satisfacerii lor. Aşa cum s-a pronunțat şi doctrina în ceea ce priveşte posibilele semnificații ale tăcerii, este absolut ilogic ca atitudinea de pasivitate a administrației să conducă la o situație iremediabilă, cu consecințe adesea catastrofale pentru particular: pierderea definitivă a dreptului său. Pentru aceasta este necesară o manifestare de voință expresă, un act administrativ. Tăcerea poate încălca un drept, neputând însă determina stingerea acestuia94.

3. În cazul de față, nu numai că în interpretarea pe care o criticăm tăcerea administrației pare să conducă la stingerea vocației particularului de a-şi valorifica un rezultat - vocație la a cărei satisfacere era în mod legitim îndreptăţit - dar, mai mult, această tăcere conduce la îngrădirea dreptului particularului de a se adresa instanței de contencios administrativ, contrar legii fundamentale dar şi legii în materie de organizare judiciarăa5.

Astfel, nici unul dintre cele două considerente contradictorii la care ajunge instanța supremă nu este satisfăcător, dificultatea analizei având ca sursă, aşadar, ambiguitatea creată prin soluția dată cauzei de față.

\footnotetext{
94 Ov. Podaru, Caducitatea actului juridic în dreptul public, Ed. Hamangiu, București, 2019, p. 166.

95 Potrivit art. 6 din Legea nr. 304/2004 privind organizarea judiciară, „(1) Orice persoană se poate adresa justiției pentru apărarea drepturilor, a libertăților și a intereselor sale legitime în exercitarea dreptului său la un proces echitabil. (2) Accesul la justiție nu poate fi îngrădit.”
} 


\section{Concluzie}

Așadar, față de întreaga analiză dezvoltată mai sus, pare evident că soluția dată de Înalta Curte de Casaţie și Justiție este criticabilă, în orice manieră am privi-o. Pe de o parte, la nivel abstract, așa cum am arătat, nu se poate deroga printr-un regulament de la legea organică, chiar în măsura în care am identifica o delegare legislativă ca cea din speță, delegare care oricum este susceptibilă de neconstituţionalitate. Din acest punct de vedere, un regulament va fi întotdeauna în conflict cu legea organică. Pe de altă parte însă, raportat la circumstanțele concrete ale speței, am constatat că, practic, regulamentul CSM nu înlocuiește vreo dispoziție din Legea nr. 554/2004 (deci nu reglementează în materia „organică” a contenciosului administrativ), având în vedere natura juridică diferită pe care o au termenul de 90 de zile și, respectiv, termenele reglementate de această lege; în concluzie, din această perspectivă, ele pot conviețui.

Însă dacă lucrurile nu se schimbă în jurisprudenţă, vocaţia magistratului la valorificarea rezultatelor concursului, în situații precum cea comentată, va rămâne una iluzorie! 